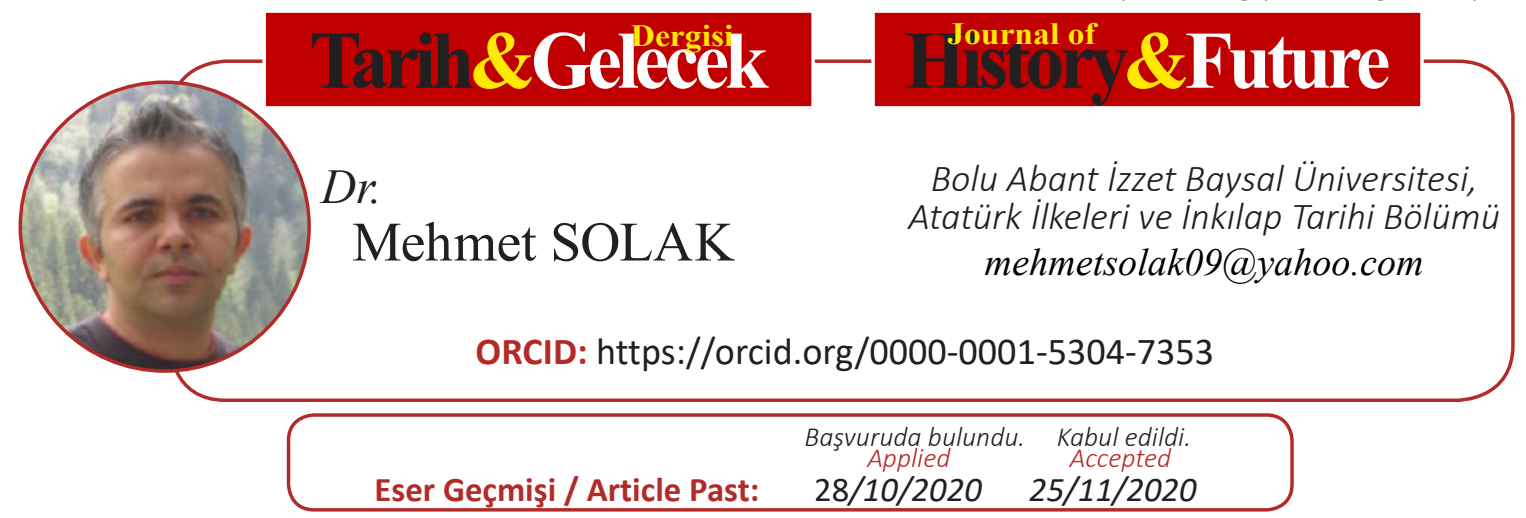

Araştırma Makalesi

DOI: http://dx.doi.org/10.21551/jhf.817778

Research Paper

Orjinal Makale / Orginal Paper

\title{
Sava ve Una Nehir Bölgelerinde Osmanl1-Habsburg Hudûd Tahdîdi (1741)
}

\section{Border Constraint in the Environments (Zones) of Sava and Tuna River (1741) \\ Öz}

Osmanlı İmparatorluğu ve Habsburg Monarşisi’nin birbirlerine karşı verdikleri mücadelenin askeri ve diplomasi tarihi paralelinde uzun bir sınır hikâyesi vardır. XV. ve XVI. yüzyıllarda Osmanlı'nın genelde Orta Avrupa'ya özelde Ortaçağ Macaristan Krallığı'nın topraklarında yayılması, bir yandan İç Avusturya bölgelerini Osmanlı baskınlarına açık hale getirmişken, diğer yandan her iki siyasal gücün tarihini şekillendiren uzun savaşlara yol açmıştır. 1735 yılında Osmanlı İmparatorluğu ve Rusya, 1737 yılında Avusturya'yı da içine alan bir savaşın içine girmişlerdir. 1720'lerin sonlarından itibaren bir Rus müttefiki olan monarşi, 1736-1737'de Kırım'daki Rus seferlerini yakından izlemiş ve bir dizi Rus zaferinden ve emellerinden dolayı alarma geçerek Temmuz 1737'de savaşa katılmıştır. Osmanlılar askeri bakımdan Romanovların müttefikinden çok daha hazırlıklı olduğunu kanıtlamış, monarşiyi en başta Banja Luka (1737) ve Grocka (1739) muharebeleri olmak üzere ağır yenilgilere uğratmıştır. Özellikle bu son muharebeden (Grocka) sonra Osmanlar Habsburgları barış masasına oturtmuş ve Belgrad Antlaşması'nı (18 Eylül 1739) imzalatmıştır. Antlaşmaya göre Osmanlı-Habsburg doğal sınırı Tuna, Sava ve Una nehirleri olmuştur. Monarşi, Belgrad ile Šabac (Böğürdelen) da içinde olmak üzere Bosna'nın kuzeyinde yer alan Sırp vilayetinin ve Kara Eflak'ın (Küçük Eflak) fiili hâkimiyetini Osmanlılara devretmiş; ancak Banat'ın Temeşvar bölgesini elinde tutabilmiştir. Özetle, Habsburg Monarşisi Pasarofça Antlaşması (21 Temmuz 1718) ile kazandığı toprakları Osmanlılara geri vermek zorunda kalmıştır.

Belgrad Antlaşması'nda sınır ve mülkiyet hakları detaylı bir şekilde belirtilmediği için 2 Mart 1741 tarihinde Osmanlar ve Habsburglar arasında bir sınır anlaşması yapılmıştır. Bu anlaşmanın coğrafya üzerinde uygulamasını ise özel hudûd tahdîd komisyonları yapmıştır. Bu çalışma Osmanlı İmparatorluğu ile Habsburg Monarşisi'nin 1699 ile 1791 yılları arasında yaptıkları antlaşmalardaki Una Nehir Bölgesi'nin sınırlarını gösteren maddelerin bulunduğu defter bağlamında, Una Nehri bölgesindeki Osmanlı-Habsburg hududunun çizimi (1741) tüm ayrıntıları ile ortaya konulmaya çalışılmıştır. Araştırmada Osmanlı arşiv belgeleri ve alan yazını ile ilgili eserlerin yanı sıra Hırvatça, Almanca, İngilizce yayımlanmış eserlere başvurulmuş; nitel araştırma yöntemlerinden içerik analizi kullanılmıştır.

Anahtar Kelimeler: Una Nehri, Sava Nehri, Bosna, Hırvat, Hudûd, Humka. 


\section{Abstract}

The struggles continued by the Ottoman Empire and Habsburg Monarchy against each other have a long border story in parallel to military and diplomacy. In 15th and 16th centuries, the expansion of the Ottomans into the Middle Europe in general and into the lands of the Kingdom of Medieval Hungary in private on one hand made the inner areas of Austria open to the Ottoman raids, on the other hand lead to the running battles that shaped the history of both political powers. The Ottoman Empire and Russia went to war in 1735 by involving Austria in in 1737. Since the end of the 1720s, the Monarchy being a Russian ally watched the Russian campaigns in Crimea closely and entered the war in July 1737 by getting alarmed due to a series of Russian victories and her desires. The Ottomans militarily proved that Romanovlar were much more prepared (on the alert) than the ally; they overwhelmed the Monarchy particularly in the battles of Banja Luka (1737) and Grocka (1739). Especially after the last battle (Grocka), the Ottomans brought the Habsburgs to the peace table and had the Treaty of Belgrade signed (18 Semptember 1739). According to the agreement, the natural border of Ottoman-Habsburg became Tuna, Sava and Una rivers. Monarchy relinquished the actual dominance of Serbian County (province) located in the north of Bosnia and Black Wallachia (Small Wallachia) including Belgrade as well as Šabac (Bögürdelen) to the Ottomans; yet kept hold of Banat's region of Temeşvar. In conclusion, Habsburg Monarchy was forced into giving the Ottomans the lands in she took the possession with the Treaty of Passarowitz (21 July 1718).

Since the border and property rights were not specified (stated) in detail in the Treaty of Belgrade, a border agreement was made between the Ottomans and Habsburgs on 2nd March 1741. As for the carrying of the agreement in the geography, the private committees of border constraint put it into practice. In this study, as a part of the land registry in which the articles indicating the boundaries of Una River Zone are available in the agreements made between the Ottoman Empire and Habsburg Monarchy between the years of 1699-1791, the Ottoman-Habsburg border (1741) in Una River Zone has been scrutinized carefully. In the research, as well as the Ottoman archival documents and the works concerning the body of literature, various works published in Croatian, German and English have been referred; the content analysis as one of the qualitative research methods has been used.

Keywords: Una River, Sava River, Bosnia, Croatian, Frontier, Humka.

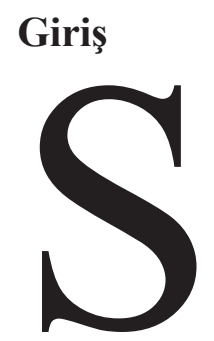

iyasal ve ekonomik ayrıcalıkların kaynadığı bir kazan olan uç bölgeleri / serhadler / sınır bölgeleri, devletlerin tarihleriyle ilişkisi temelinde oluşmuş olan mekânlardır. Bu mekânlar tarih boyunca savaşlar aracılığıyla bulundukları bölgelerden ileriye / geriye doğru ilerletildikleri / geriletildikleri için esnek bir yapı sergilemişlerdir. Sınır bölgelerinin Vestfelya Antlaşması'ndan (1648) itibaren siyasal merkezlerin mülkiyetlerini ve otorite alanlarını bölen çizgisel sınırlara dönüşmelerine ${ }^{1}$ rağmen eyaletlerin ve

1 Alexander C. Diener \& Joshua Hagen, Borders: A Very Short Introduction, Oxford: Oxford University Press, 2012, ss. 2-3. Vestfalya düzenin kısa bir değerlendirmesi için bkz.: James A Caporaso, "Changes in the Westphalian Order: Territory, Public Authority and Sovereignty.", International Studies Review, 2000 (2/2), ss. 1-28. 
bölgelerin hudutları önemlerini korumaya devam etmiştir. Ayrıca savaşların birçoğunun yetersiz veya kabul görmemiş bölgesel düzenlemeler sonucunda çıktığı dikkate alındığında, sınırların barışın yaratılmasında ve sonrasında çok önemli olduğu ortaya çıkmaktadır. Bu bağlamda sınırları savaşlar aktif hale getirirken barış antlaşmaları pasif hale dönüştürmüştür. Fakat bazen kendi barış süreçlerinin son aşaması olamayan resmi antlaşmaların sınır maddeleri üzerinde farklı yorumlar ortaya çıkmıştır. Bu çelişkili yorumların detaylı açıklanması ve arazi üzerinde sınır hatlarının tespiti için tek bir yöntem uygulanmıştır: diplomasi. Süreç komisyon üyelerinin arazi üzerindeki kapsamlı çalışmalarını, uzun müzakereleri, toprak değişimini, ayrıntılı haritalandırma, sınır protokollerinin yapılması ve sınır işaretlerinin dikilmesini içermiştir. Müzakerelerin amacı ise, tarihsel hakları ve iddiaları göz ardı ederek mali, askeri ve adli bölgesel birliği sağlayacak bir uzmanlaşmaydı.

Genelde Vestfelya özelde Karlofça (1699) antlaşmalarından² sonra gerçekleştirilmeye başlanan sistematik sınırlamalar ve yeni sınırların uygulanması XVIII. yüzyılın ortalarından itibaren Batı ve Orta Avrupa'daki pek çok ülkede görülmeye başlanmıştır. Bu sistematik sınırlandırma hareketleri 1730'ların sonlarında gerçekleştirilmiş ve aynı yüzyılın ikinci yarısından itibaren tüm hızıyla devam etmiştir. ${ }^{3}$ Böylece devlet sınırları uluslararası sistemin yapılanması için çok önemli hale gelmiştir. Bu bağlamda siyasi iktidarı mekânsal terimle tanımlamanın örneklerinden biri olan Osmanlı-Habsburg sınır hattının Belgrad Antlaşması sonrasında belirlenmesi büyük önem arz etmektedir.

Osmanlı ve Habsburg güçleri arasında 17. ve 18. yüzyıllarda diplomasi üzerine çoğalan araştırmalarla karşılaştırıldığında hudut tahdidi konusu yeterince ele alınmamıştır. ${ }^{4} \mathrm{Bu}$ nedenle çalışma, 1699 ile 1791 yılları arasında Osmanlı İmparatorluğu ile Habsburg Monarşisi'nin yapmış oldukları antlaşmalardaki Una Nehir Bölgesi'nin sınırlar hattını gösteren maddelerin bulunduğu defter çerçevesinde, Belgrad Antlaşması (1739) sonrası Osmanlı İmparatorluğu ile Avrupa arasındaki Una Nehir bölgesindeki hududu değerlendirmeyi amaçlamaktadır.

\section{Savaş Üzerine (1736-1739)}

Osmanlı İmparatorluğu ile Habsburg Monarşisi arasındaki ilişkilerde XVIII. yüzyıl, çok dalgalı bir dönem olarak karşımıza çıkmaktadır. Avrupa harp tarihi yazıcılığı perspektifinden

2 Karlofça Antlaşması sonrası Osmanlı-Habsburg sınırının değişimi üzerine bkz.: Rifa at. A. Abou-El-Haj, "Ottoman Diplomacy at Karlowitz", Journal of the American Oriental Society, 1967 (87/4), ss. 498-512; Rifa'at. A. Abou-El-Haj, "The Formal Closure of the Ottoman Frontier in Europe:1699-1703”, Journal of the American Oriental Society, 1969 (89/3), ss. 467-475; Monika Molnor, "Karlofça Antlaşması'ndan Sonra Osmanlı Habsburg Sinırı (1699- 1701)", Osmanl, C. I, Ankara: Yeni Türkiye Yayınları, 1999, ss. 472-479. Ayrıca genel itibari ile Osmanlı-Venedik ilişkileri bağlamında Karlof̧̧a Antlaşması'nın bir değerlendirmesi için bkz.: Güner Doğan, "Venediklü ile Dahi Sulh Oluna": 17. ve 18. Yüzylllarda Osmanll-Venedik İlişkileri, İstanbul: İletişim Yayınları, 2017, ss.98-217.

3 Jovan Pešalj, Monitoring Migrations: The Habsburg-Ottoman Border in The Eighteenth Century, Doctoral Thesis, Universiteit Leiden, 2019, ss. 15-17.

4 Karlofça Antlaşması (1699) sonrası belirlenen Osmanlı-Habsburg sınır hattı için bkz.: Turan Gökçe, "1699-1700 Tarihli Bosna Vilâyeti Hududnâmesi”, Tarih İncelemeleri Dergisi, 2001 (XVI), ss. 75-104. Ziştovi Antlaşması (1791) sonrası belirlenen Osmanlı-Habsburg sınır hattı için bkz.: Mehmet Solak, "Osmanl1-Habsburg Hudûd Tahdîdine Bir Örnek: Ziştovi Sonrası Bosna Hudûdunun Tafsilatı (27 Aralık 1795)", Karadeniz Araştırmaları, 2020 (XVII/67), ss. 631-656. Pasarofça sonrası Osmanlı-Habsburg sınır hattının tafsilatı üzerine bir çalışma yapılmamış, fakat hudut tahdid çalışmaları üzerine yapılmıştır. Bkz.: Uğur Kurtaran, "Pasarofça Antlaşması’na Göre Yapılan Sınır Tahdit Çalışmaları ve Belirlenen Yeni Sınırlar”, Uluslararası Sosyal Araştırmalar Dergisi, 2018 (11/55), ss. 285-300. 
bakıldığında bu yüzyıl iki siyasal güç arasında üç savaşın yapıldığı bir dönem olarak işaretlenirken, Türk harp tarihi yazıcılığı ise Ruslarla çatışmalara odaklanmıştır. Fakat bu yoğunlaşmaya rağmen Osmanlıların XVIII. yüzyılda Batılı güçlerle yaşadığı çatışmanın ağırlık merkezini Habsburglar ile yaptı̆̆ savaşlar oluşturmuştur. Tarafların aynı zamanda tarihlerini de şekillendiren savaş halinin en önemli zaman dilimini oluşturan 1737-1739 tarihleris, 1714-1718 tarihleri arasında yaşanan çatışmanın bir rövanşı niteliğindeydi.

Romanovlar (Rusya), Lehistan Veraset Savaşı (1733-1738) sırasında Bourbonlar'ın (Fransa) Osmanlılardan askeri yardım istemeleri ve kendilerinin Ukrayna ile Kırım üzerindeki yayılma arzuları gibi farklı sebeplerden dolayı 1736 yılında Osmanlı İmparatorluğu'na savaş ilan etmiştir. Avrupa tarihinde 1736-1739 Rus-Türk Savaşı olarak bilinen bu çatışmaya Kırım Tatarların Rus Ukrayna'sına yaptığı yıkıcı baskınlar neticesinde ${ }^{6}$ Habsburglar Romanovların müttefiki olarak 14 Temmuz 1737 tarihinde, isteksiz (!) bir biçimde katılmışlardır.? İmparator VI. Karl Osmanlı'ya karşı savaşa, donanımsız ve zayıf askeri liderlerin elindeki bir orduyla girmiş, Osmanlılar ise hazırlıksız olarak yakalanmışlardır. ${ }^{8}$

Tüm bu olumsuzluklara rağmen monarşinin harp stratejisi, Rus kuvvetlerinin Eflak ve Boğdan üzerinde yoğunlaştığı sırada kendi ordularını Bosna sınırlarına, özellikle 1718'den sonra Osmanlıların Avrupa sınırlarındaki ana kalesi olan Vidin ve Morava Nehri üzerindeki Niş’e saldırmak üzerine oluşturulmuştur. Bu sevk ve idare bağlamında Dük Franz Lorenski topladığ 122.540 askerden oluşan orduyu 12 Temmuz 1737 tarihinde üç gruba bölerek üç farklı yerden saldırmayı planlamıştır. Buna göre ana birlikler Feldmeraşal Friedrich Heinrich von Seckendorf komutasında Büyük Morava vadisinden Niş’e kadar nüfuz edecek ve Vidin'e saldıracaktır; Doğu Birlikleri -Tuna'nın sol kıyısında- George Olivier Wallis komutasında Bükreş'e kadar nüfuz edecek,

$5 \quad$ George Childs Kohn, Dictionary of Wars, London ve New York: Routledge, 2013, s. 421.

6 Romanovlar Osmanlılar ile savaşın çıkması için gerekli zemini fiilen oluşturmuşlar; 1723’ten beri Osmanlıların fiilen savaş halinde (1723-1727, 1730-1732, 1735-1736) olduğu İran ile birkaç antlaşma imzalamış ve III. Augustus'u Fransız himayesinde olan Stanislaw Leszczynski yerine Lehistan tahtına yerleştirip kendilerine çok elverişli bir uluslararası pozisyon sağlamışlardır. Bkz.: Josef Matuz, Osmansko Carstvo, Zagreb: Školska Knjiga, 1992, s. 125.

7 Virginia H. Aksan, "Austro-Ottoman War (1736-1739)", The Encyclopedia of War, (Ed.) Gordon Martel, Chicester: Wiley-Blackwell, 2012, s. 1. Habsburglar Romanovlarla 1726 y1lında yaptıklar1 antlaşmadan dolayı 1736-1739 Osmanlı-Rus savaşına dahil olmuşlardır. Monarşi Romanovlar ile yaptığı ittifak ile özelde Eflak ve Boğdan'ın Romanovlar tarafından işgal edilmesini önlemek isterken genelde Romanovların Güneydoğu Avrupa üzerindeki yayılmasını engellemek istemiştir. Vaníček Avusturya’nın bu savaşa İtalya'da yaşadığı kayıpları Balkan Yarımadasında telafi etmek amacıyla girdiğini belirtmiştir. Bkz.: František Vaníček, Specialgeschichte der Militargrenze Aus Originalquellen und Quellenwerken Geschopft, II. Band, Wien: Hof- und Staatsdruckerei, 1875, s. 314. Habsburglar savaşmaya niyetleri olmadığg söylentisini bilerek de yaymış olabilirler; çünkü Osmanlılar bu söylentinden dolayı Yukarı Tuna'da seferberliği alışıllmadık ölçüde geç sağlamışlardır. Bkz.: Virginia H. Aksan, Kuşatılmış Bir Imparatorluk: Osmanlı Harpleri 1700-1870, (çev.) Gül Çağalı Güven, İstanbul: Türkiye İş Bankası Kültür Yayınları, 2. Baskı, 2011, s. 122. Novili Ömer Efendi ise Habsburgların başlangıçta kendisini barış taraftarı olarak göstermesinin sebebini Osmanlıların tüm gücüyle Rusya üzerine yöneldiği sırada monarşinin Bosna'ya saldırmayı planladığını belirtmiştir. Bkz.: Novili Ömer Efendi, Tarih-i Bosna: Osmanlı-Habsburg Savaşları 1736-1739, (haz.) Fatma Sel Turhan, İstanbul: Küre Yayınları, 2016, s. 25, 49.

8 Aksan Habsburgların kendi birliklerini “uzun süre başka yerlerde konuşlandirdığ için, bu cephede orduyu sıfırdan inşa etmek zorunda kaldı̆̆ını... Osmanlıların tipik olarak geç harekete" geçtiğini belirtmiştir. Bkz.: V. H. Aksan, “a.g.m”, s. 1. 
Tuna Nehri'nin sol yakasında faaliyetlerini yoğunlaştırarak Erdel üzerinden Eflak ve Boğdan'a hücum edecek; Askeri Sınır Bölgesi ve Banska Hrvatska'dan takviye edilmiş Batı Birlikleri Joseph Friedrich Hildburghausen komutasında Hırvat Banı Kont Esterhazy'ın emrindeki on bin kişilik sınır muhafazıyla birlikte Slavonya, Hırvatistan ve Lika'dan Sava'yı geçip, yoğun bir saldırı ile Banja Luka ve kuzeybatı Bosna'yı fethedeceklerdir. ${ }^{9}$

Yapılan planlara rağmen savaşın askeri operasyonlarının seyri Monarşi açısından beklenmedik bir yönde ilerlemiştir. Askeri beceriksizlik, iaşe organizasyonundaki yetersizlik, operasyonel iletişim yönetiminin zayıf olması gibi sorunların büyüklügünü yeniden gündeme getiren Tuna cephesindeki Osmanl1-Habsburg muharebeleri sirasinda "zafer ve ricat" modeli sik sık yaşanmıştır. Osmanlıların 1737 yılında kaybettikleri Niş’i aynı yıl geri almaları, Orsova'da monarşi birliklerini Tuna sahiline doğru sıkıştırmaları, Belgrad'a giden garnizonları güvence altına almak için 1738 yılında Hekimoğlu Ali Paşa’nın komutasında Morava Vadisi'ndeki Čačak, Sitnica, Rudnik, Užice gibi stratejik garnizonları ele geçirmeleri ve Tuna'nın kuzeyindeki Orsova ve Adakaleyi düşürmeleri ${ }^{10}$ Tuna' daki savunma hattını yeniden oluşturmalarına sebep olmuştur. ${ }^{11}$

Viyana yönetimi Osmanlılar karşısındaki bu başarısızlıklardan sonra 1739 yılında muharebeleri daha başarılı bir şekilde sürdürebilmek ve bitirmek için ordularına başkomutan olarak feldmareşal Wallis'i atamıştır. Monarşinin planı, ilk önce Wallis'in komutasındaki birliklerin Vezir İvaz Mehmed Paşa komutasındaki Osmanlı birlikleri karşısında Grocka ${ }^{12}$ yakınlarında mağlup olması, sonra Hekimoğlu Ali Paşa ve Bosnalı müfrezelerin Pokupska Krajina’yı harap etmesi ve en sonunda İbrahim Paşa'nın Lika'ya baskın düzenlemesinden dolayı başarısız olmuştur. ${ }^{13} 1739$ yılında monarşinin, özellikle başkomutan Wallis ilk hedefi Osmanlı İmparatorluğu'nun Belgrad'1 kuşatmasını engellemek olacaktır. Fakat Wallis'in, ordusunu on yedi mil geride olan Tuna sahiline doğru geri çekmesi Belgrad Kalesi'ni açıkta bırakması ve Grocka Savaşı'nda stratejik açıdan bir taktik hatası olarak görülmüş ve Osmanlıların kaleyi kuşatmasına sebep olmuştur. Sözü edilen geri çekilmeden sonra monarşinin ana politikalarının belirleyici organı olan Geheime Konferenz, barış yapma yetkisini başkomutandan alarak, 1718 yılında Osmanlı-Habsburg arasındaki sınırları belirleyen müzakerelerde baş delege olarak görev yapmış Kont Reinhard William Neippeng’e vermiştir. ${ }^{14}$

9 F. Vaníček, a.g.e., ss. 314-315; V. H. Aksan, “a.g.m”, s. 1; V. H. Aksan, a.g.e., s. 129; Johann Wilhelm Zinkeisen, Osmanlı Imparatorluğu Tarihi, (çev.) Nilüfer Epçeli, C.V, İstanbul: Yeditepe Yayınları,2011, s. 501. Novili Ömer Efendi Habsburg Monarşisi'nin Bosna'yı beş koldan işgal etmek için birliklerini beş tabura böldüğünü; birincisinin Banaluka'nın karşısındaki Gradiška'da, ikincisinin Bužin ve Cetin kalelerinin karşısında, üçüncüsünün Ostrowiz bölgesinde, dördüncüsünün İzvornik Kalesi karşısında konuşlandıklarını; beşinci taburun ise Bosna'nın Rumeli ve Arnavutluk ile irtibatını kesmek için anayol ve geçitleri kapatacağını, Niş Kalesi’ni ele geçirip Yenipazar’a saldıracağını belirtmiştir. Bkz.: Novili Ömer Efendi, a.g.e., s. 25, 49-50.

10 Muharebelerin monarşi tarafından detaylı bir anlatısı için bkz.: Major Moriz von Angeli, "Der Krieg mit der Pforte, 1736 bis 1739”, Mitteilungen des k.k. Kriegsarchivs (1881), ss. 247-298, 409-79; Karl A. Roider, The Reluctant Ally: Austria's Policy in the Austro-Turkish War,1737-39, Baton Rouge: Louisiana State University Press, 1972.

11 Virginia H. Aksan, "Savaş ve Barış”, Türkiye Tarihi: Geç Osmanlı Imparatorluğu 1603-1839, C. III, (ed.) Suraiya Faroqhi, (çev.) Fethi Aytuna, İstanbul: Kitap Yayınevi, 2011, s. 129.

12 Hisarcik.

13 Vojna Enciklopedija, Knj. 1, Izdanje Redakcije Vojne Enciklopedije, Beograd, 1958, s. 374.

14 Geheime Konferenz Neippeng'e barış görüşmelerinde uyması için 10 Ağustos 1739 tarihinde bir talimat 
Habsburgların Grocka başarısızlığı sonrasında Belgrad Kalesi'ni kuşatması, daha sonra da Pançova'da Osmanlı birliklerine yenilmesi barış görüşmelerinin başlamasına sebep olmuştur. ${ }^{15}$ Görüşmeler 16 Ağustos 1739 tarihinde, I. Mahmud tarafından Osmanlılar adına barış antlaşması için pazarlık yetkisi verilen Fransa sefiri Marquis de Villeneuve ile Neippeng arasında başlamışıtır. Neippeng'in Viyana'dan sağlıklı haberler alamadığ 1 ve Wallis ile arasındaki çekişmelerden dolayı muharebe meydanındaki statükonun değişmesini takip edemediği için Belgrad'1, Fransa'nın garantörlüğünde Osmanlılara teslim etmeyi kabul etmiştiri ${ }^{16}$

\section{Harbi, Diplomasiyle Sona Erdirmek: Belgrad Barışı'na Göre Bosna Hudûdu}

Belgrad, Özi ve Azak hattındaki sınırlar üzerinde Osmanlı-Habsburg-Romanov güçlerinin mücadelesinin bir aşaması olan"17, Habsburg Monarşisi açısından "Talihsiz Türk Savaşı" olarak da nitelendirilen ve VI. Karl'ın hayatının son yıllarını gölgeleyen ${ }^{18}$ 1737-1739 Osmanl1-Avusturya Savaş1; 18 Eylül 1739 tarihinde imzalanan Belgrad Barış Antlaşması ile sona ermiştir. ${ }^{19}$ Yirmi yedi yıllığına ${ }^{20}$ yapılan Belgrad Antlaşması, Osmanlı idaresi altındaki eski Bosna topraklarını Karlofça'dan sonra daha da daraltan Pasarofça Barışı'nın kazanımlarını aşağı yukarı ortadan kaldırmıştır. ${ }^{21}$ Osmanlılar Batı Morava'nın kuzeyindeki Sırp topraklarını geri alarak Habsburg hâkimiyetindeki Belgrad ${ }^{22}$ ve Šabac (Bögürrdelen) $)^{23}$ da içinde olmak üzere Sirbistan Vilayetinin /

vermiştir. Buna göre, monarşinin sahra ordusu Belgrad yakınlarında konuşlandırılacak, eğer Belgrad Kalesi'nin Osmanlıların eline geçmesi engellenirse, Fransa'nın arabuluculuğuyla Avusturya Sırbistan'ı ve Küçük Eflak Osmanlılara bırakılacak; Belgrad Kalesi'nin savunması sıkıntılıysa, Osmanlı kalesi olan Yeni Orşova'nın yıkılması karşılığında Belgrad'ın modern surlarının ortadan kaldırılması görüşü öne sürülecek; Belgrad Kalesi hiç direnemeyecek durumdaysa kalenin tahkimatları yerle bir edildikten sonra Osmanlılara teslim edilecektir. Böylece Sava ve Tuna nehirleri Osmanl1-Habsburg hududu haline gelecektir. Karl A. Roider, "The Perils of Eighteenth-Century Peacemaking: Austria and the Treaty of Belgrade, 1739”, Central European History, Sep., 1972, Vol. 5, No. 3 (Sep., 1972), ss. 198-199; Karl A. Roider, Austria's Eastern Question, 1700-1790, New Jersey: Princeton University Press, 1982, s. 85.

15 Grocka ve Pançova muharebeleri için bkz.: Hakan Karagöz, 1737-1739 Osmanll-Avusturya Harbi ve Belgrad'in Geri Alınması, Doktora Tezi, Süleyman Demirel Üniversitesi Sosyal Bilimler Enstitüsü, Isparta, 2008, ss. 162-241.

16 K. A. Roider, “a.g.m.”, ss. 197-204.

17 V. H. Aksan, a.g.e., s. 87.

18 F. Vaníček, a.g.e., I. Band, s. 473.

19 Belgrad Antlaşması için bkz.: BOA, Nemçelü Ahidnâmesi, 59/3, ss. 185-191; Uğur Kurtaran, Osmanlı Diplomasi Tarihinden Bir Kesit: Osmanlı Avusturya Diplomatik İlişkileri (1526-1791), İstanbul: Ukde Yayınlar1, 2009, ss. 218-227.

20 Antlaşmanın yirmi üçüncü maddesi için bkz.: BOA, Nemçelü Ahidnâmesi, 59/3, s. 190.

21 Milan Kruhek \& Augustin Pavlović, "Granice Republike Hrvatske u svjetlu Karlovačkog (1699) i Požarevačkog (1718) Mira”, Croatica Cristiana Periodica, 1991 (28/15), ss. 112-115, 129-135; Sij Srkulj, "Uređenje Međa po Karlovačkom i Požarevačkom Miru”, Vjesnik Kraljevskog HrvatskoslavonskoDalmatinskoga Zemaljskoga Arkiva, (ur.) Ivan Pl. Bojničić Kninski, Zagreb: Tisak Kralj. Zemaljske Tiskare, 1907, ss. 38-43; Milan Kruhek, "Granice Hrvatskog Kraljevstva u Međunarodnim Državnim Ugovorima. (Od Mira na Žitvi 1606. do Mira u Svištovu 1791.)”, Povijesni Prilozi, 1991 (10), ss. 69-71.

22 Antlaşmanın birinci maddesi için bkz.: BOA, Nemçelü Ahidnâmesi, 59/3, s. 186. Ayrıca Belgrad'ın teslim edilme süreci için bkz.: Hakan Karagöz, "Belgrad-1 Dârü'l-Cihâd'da Osmanlı Hâkimiyetinin Yeniden Tesisi (1739)", Güney-Doğu Avrupa Araştırmaları Dergisi, 2018 (33), ss. 183-205. 
Kraljevina Srbija (1718-1739) $)^{24}$ varlığını sona erdirmiştir. ${ }^{25}$ Orsova $^{26}$ ve Küçük Eflak ${ }^{27}$ ve Pasarofça Barışıyla elde edilen Bosna toprakları -Furjon Bölgesi hariç-28 Osmanlılara teslim edilmiştir. vusturya Temeşvar Banat'ı elinde tutmuş, ancak işgal sırasında inşa ettiği tüm kaleleri ve ayrıca Tuna Nehri boyunca Osmanlılara doğru uzanan kaleleri yıkarak boşaltmak zorunda kalmıştır. ${ }^{29}$ Monarşi böylece Sava sınırında Bosna'dan sözde Uskok Bölgesi'ni ${ }^{30}$ ve Banat sınırında Bosna'dan iki voyvodalık arazisini kaybetmiş̧tir. ${ }^{31}$ Hırvat coğrafyasındaki doğal sınır ise Una Nehri olmuştur. Özetle, Osmanlılar Tuna ve Sava'nın güneyindeki/sağındaki tüm toprakların yanı sıra Küçük Eflak ile birlikte daha önce kaybettiği toprakların büyük bir kısmını geri almayı başararak monarşiyi Balkan Yarımadası'nın dışına itmiştir. ${ }^{32}$

Habsburg Monarşisi’nin Rusya ile Osmanlı arasındaki barış görüşmelerinin sonuçlanmasına kadar Belgrat’taki güçlerini geri çekmeyi ertelemesi, Osmanlıların sınırlarını mümkün olduğunca batıya doğru hareket ettirmek istemesi, VI. Karl'ın ölmesi sonucunda Maria Theresa'nın tahta geçmesi, Prusya'nın Silezya saldırısı sonucunda monarşinin dikkatini Prusya üzerine yoğunlaştırması gibi sebepler Viyana ile İstanbul arasında hudut müzakerelerinin başlamasını geciktirmiştir. ${ }^{33}$ Fakat Osmanlılar, İran ile ilişkilerinin gerilmesinden dolayı monarşi ile olan hudut sorununu çözmek için yoğun çaba sarf etmiştir. Her iki tarafın muhaddidleri Mayıs 1740 tarihinde

24 Habsburg egemenliği altında 1718 yılında oluşturulan Kraljevina Srbija, bugünkü Sırbistan Cumhuriyeti'nin orta kesimlerinde var olan vilayetinin adıdır. Bölge, kuzeyde Belgrad'dan doğuda Bosna'daki Bijeljina'ya ve batıda Romanya ve Bulgaristan'ın bazı kısımlarına uzanan bir alanı kapsamaktadır.

25 Antlaşmanın üçüncü maddesi için bkz.: BOA, Nemçelü Ahidnâmesi, 59/3, s. 186.

26 Antlaşmanın beşinci maddesi için bkz.: BOA, Nemçelü Ahidnâmesi, 59/3, ss. 186-187.

27 Antlaşmanın dördüncü maddesi için bkz.: BOA, Nemçelü Ahidnâmesi, 59/3, s. 186.

28 Branislav Đurđev, "Bosna Hersek", TDV İslâm Ansiklopedisi, C. VI, İstanbul: Türkiye Diyanet Vakf1 Yayınlar1, 1992, s. 301.

29 Antlaşmanın altıncı maddesi için bkz.: BOA, Nemçelü Ahidnâmesi, 59/3, s. 187.

30 Sözde Uskok Bölgesi, Una-Drina nehirleri arasında ve Sava Nehri’nin güneyinde bulunmaktadır.

31 F. Vaníček, a.g.e., I. Band, ss. 473-474.

32 Belgrad Antlaşması’nın yedinci maddesinde Hırvat coğrafyasında doğal sınırın Una Nehri olduğu belirtilmiştir: "Tuna Nehri ve Sava Nehri sahilleri bir taraftan Osmanlı Devleti ve bir taraftan Roma İmparatoru'na aittir. Bunun sonucunda gelir getiren gerek her çeşit balık avı gerek hayvanları sulamak ve her iki tarafın halkına gereken ortak faydaları olmaktadır. Ancak her taraftan balık avı için nehre saldırılmaya ve açıklar üzerinde olan su değirmenleri, tüccarın geliş gidiş yapan gemilerine engel olmamak üzere sınırlarda olan zabitanca uygun görülen yerlerde yapılacaktı. Her iki tarafın yararı ve kolaylığı için halkın gemileri engelsiz bir şekilde suyun akıntısına göre kendilerine ait olan yerden ve her iki tarafın yedeklemesi mümkün olmadığında karşı taraftan yedeklemesi uygun olacaktı. Tuna Nehri ve Sava Nehri'nde bulunan ve yeniden ortaya çıkan adalar hakkında çekişme olduğunda gelecekte açıkça bildirilecek olan maddenin üzerine belirlenecek sınırlarla bu tür adalar hangi tarafın kıyılarına yakın bulunursa o tarafa ait olacaktır. Sınırların belirlenmesi adı geçen adaların ayrılması maddesinde belirlenecek sürede her iki tarafın yüzölçümü olacak ve her iki tarafın halkının kolaylığı için sınırların sonunda ev ve karyeler yapılmasının engellenmemesi uygun olacaktır.” Bkz.: BOA. A. DVNS., Nemçelü Ahidnâmesi, 59/3, s. 187; BOA, HAT, 1431-58588, Belge 3, s. 2.

33 Bu konuda İstanbul'daki monarşi elçisi Kont Ullefeld, 7 Temmuz 1740 tarihinde Habsburg birliklerinin Belgrad'tan tamamen geri çekilmesi ile hudutların tahdidi üzerine müzakerelerin durmamak kaydıyla başlayacağını bildirmiştir. Bkz.: Ive Mažuran, "Razgraničenje Između Carske Austrije i Osmanskog Carstva od Utoka Save u Dunav do Novog na Uni 1741. Godine", Anali Zavoda za Znanstveni Rad JAZU u Osijeku, 1984 (3), s. 175. 
Belgrad'da toplanmış, lakin herhangi bir ilerleme sağlayamamışlardır. ${ }^{34}$

\section{Osmanlı-Habsburg Hudûdlarının Tefrîk ü Temyîzi: Sava ve Una Nehir Bölgeleri (6 ve 11 Mayıs 1741)}

Barış antlaşmaların ana konularından biri olan sınırların hatlarını, antlaşma sonrası oluşturulan tahdî̀-i hudûd komisyonları belirliyordu. Barış antlaşmasına uygun olarak, barışın daha da sağlamlaştırılması ve karşılıklı memnuniyetin tamamlanması için, her iki tarafın muhaddidlerinin bilgisi ile belli yerlere sınır işaretleri (humka) konularak sınır hatları yeniden düzenlenirdi. Osmanlı merkezi idaresi Belgrad Antlaşması'ndan sonra hudûdların tefrîk ü temyizi konusunda Belgrad bölgesi için Mevkûfâtî El-hac Mehmed Efendiyi, Temeşvar bölgesi için Divan-1 Hümayun kapıcıbaşısı İbrahim Efendiyi, Bosna bölgesi için de Mehmed Said Efendiyi görevlendirmiştir. ${ }^{35}$ Fakat çeşitli zorluklarından dolayı sınır düzenlemesi uzun süre çözülemeyen bir sorun haline gelmiştir. Bunun sonucunda Fransız elçi Villeneuve'nin arabuluculuğuyla taraflar yeni hudutlar üzerine 2 Mart 1741/14 Zil'-hicce 1153 tarihinde bir anlaşmaya varmıştır. ${ }^{36}$

Anlaşma gereğince Drina Nehri'nden yukarıya doğru Bosna Eyaleti'nin sonunda olan Una Nehri'nin Sava Nehri'ne karıştığı yere (Jasenovac Palankası Bölgesi), oradan da Novi-i Atik Kalesi sınırına kadar uzanan yerlerde ne kadar karakol, çardak, hisar ve kale varsa boşaltılması ve tahrip edilmeden Osmanlı İmparatorluğu'na antlaşma tarihinden kırk beş gün sonra teslim edilmeleri kararlaştırılmıştır. ${ }^{37}$ Bundan başka, Sava Nehri'nde olan Ciganlija Adası denilen büyük adanın Osmanlı tasarrufunda kalması, bu adadan başka Una Nehri'nin Sava Nehri ile birleştiği yere kadar olan küçüklü büyüklü adaların ise monarşi hâkimiyeti altına bırakılması üzerinde anlaşılmışıır³.

Una ve Sava nehir bölgelerinde sınırların çizilmesi konusunda farklı yorumların ortaya çıkması sonucunda yapılan 2 Mart 1741 tarihli temessüke göre ${ }^{39}$, Sava Nehri'nin Tuna Nehri'ne karıştığı boğazdan Bosna Eyaleti'nin sonu olan Una'nın Sava'ya karıştığı yere kadar ve adı geçen yerden de Bosna tarafindaki Una sahiliyle devam edilip hala Osmanlı tasarrufunda olan Novi-i Atik Kalesi sınırına kadar Karlofça Sınır'ı ve Una Nehri'nin karşı tarafının/ötesinin, yani Hırvat taraflarının hudûd-1 selâseye kadar olan bölümü Pasarofça Sınır'1 ile belirlenecektir. ${ }^{40}$ Böylece Sirp Eyaletinin sonu olan Drina Nehri'nden yukarı Bosna tarafinda iki devletin sınırı Sava ve Una nehirleri olup, iki devlet bu nehirlerin ötesinde bir şey talep etmeyecektir. Sava ve Una nehirlerine her iki tarafın saldırmaması, balık avı vb. çıkarlarından her iki tarafın halkının eşit bir şekilde ortaklaşa kullanmasına karar verilmiştir. ${ }^{41}$ Bunların yanında, Tuna nehir adalarından Pavirza

34 J. W. Zinkeisen, a.g.e., s. 563.

35 H. Karagöz, a.g.t., s. 290; Uğur Kurtaran, "Ottoman-Austria Border Determination Works and Newly Determined Borders According to the Treaty of Belgrade of 1739", Belgrade 1521-1867, (Ed.) Dragana Amedoski, Belgrade (2018), s. 177.

36 BOA, HAT, 1431-58588, Belge 5, s. 3.

37 BOA, HAT, 1431-58588, Belge 4, ss. 2-3.

38 BOA, HAT, 1431-58588, Belge 4, s. 3.

39 Temessük dört madde ve bir hatimeden oluşmuştur. Temessük için bkz.: Treaties Between Turkey and Foreign Powers.1535-1855, London: Compiled by the Librarian and Keeper of the Papers, 1855, ss. 108111; BOA, HAT, 1431-58588, Belge 5, ss. 3-4.

40 Bundan sonra metin içinde Karlofça Antlaşması sonrası belirlenen hudûd için “Karlofça Sınırı”, Pasarofça Antlaşması sonrası belirlenen hudûd için "Pasarofça Sınırı" terimleri kullanacaktır.

41 BOA, HAT, 1431-58588, Belge 4, ss. 2-3; Temessükün birinci maddesine bkz.: Treaties Between Turkey 
(Pavizza), Kissilova (Kisselova) ve Grocka Osmanlıya; Orsova Kalesi'nden Belgrad'a kadar irili ufaklı olan adalar ise Habsburglara ait olacaktır. Ciganlija Adası denilen büyük Sava adası Osmanlı hükümranlığı altında olurken, Una'nın Sava'ya karıştığ1 yere kadar olan tüm irili ufaklı nehir adaların ise monarşi egemenliğine bırakılması kararlaştırılmıştır. ${ }^{42}$

Sınırın kesin çizgi şeklinde belirlenebilmesi için 1741 tarihli temessük tahdîd-i hudûd komisyonlarına gönderilmiştir. Fransa'nın garantisiyle Sava'nın Tuna'ya karıştığı yerden Una üzerindeki Novi-i Atik’e kadar olan bölgenin sınırlandırma çalışmaları 6 Nisan 1741 tarihinde başlamıştır. Komisyonlar kırk beş gün içinde adı geçen bölgelerde Osmanlı İmparatorluğu ile Habsburg Monarşisi arasındaki sınırları belirleyecek ve Novi-i Cedid'den hudûd-1 selâseye kadar olan daha önceden belirli aralıklarla, iki tarafça işaretlenmiş, rakamlı hudut işaretlerini (Hunke, Grenzmarke, Chumka) yenileyeceklerdir. Sava Nehri içindeki nehir adalarının hukuki durumlarını belirlemek için oluşturulan komisyon çalışmasını 6 Mayıs 1741 tarihinde bitirirlerken; Una nehir bölgesinde sınırları belirlemek için kurulan komisyon ise 11 Mayıs 1741 tarihinde faaliyetlerini sonuçlandırmıştır. Una Nehir bölgesinde sınırları Slavonya generali Ascanio Antonio Marquis de Guadagni başkanlığındaki monarşi komisyonu ile Rumeli beylerbeyi Mehmed Sait Efendi başkanlığındaki Osmanlı komisyonu yeniden belirlemiştir. ${ }^{43}$ Sava Nehri içindeki on üç nehir adasının yedisi Osmanlı hâkimiyetinde kalmıştır. Una nehir bölgesinde ise Jasenovac (Palanka), Novi-i Atik, Çetin, Kladuš kale arazilerinin; Drežnik, Izačić ve Bihać kalelerinin karşısındaki yaylaların; Lapatz Çiftlik, Poricsovatz, Ostrovica kale arazilerinin ve Srb Nahiyesinin hudutları tüm detayları ile tarif edilmiştir.

\subsection{Sava Nehrinde Osmanlı-Habsburg Hudûdu (6 Mayıs 1741): Sava Nehir Adalarının Hukuki Durumları}

Sava Nehir bölgesi için oluşturulan komisyon, Sava Nehir adalarının hukuki durumu belirlendikten sonra bunu bir temessükle yazılı hale getirmiştir. Bu temessüke göre, iki devletin sınırı olan Sava ve Una nehirlerinde balık avı vb. kabul edilmiş iştirak ve yedek şartlara uyulması şartıyla Belgrad'dan Drina Nehri'ne kadar Baliş ${ }^{44}$, Šabac ${ }^{45}$ ve Maçova ${ }^{46}$ nahiyeleri kıyıları ve daha yukarıdaki Bosna Eyaleti'nde olan Boyna Tuzla, Grad Çaniçe ${ }^{47}$, Teşne ${ }^{48}$, Derbend ve Banaluka ${ }^{49}$ kazaları sahillerinden Uskon ${ }^{50}$ denilen arazide olan Belene ve Novi-i Atik ${ }^{51}$ Kalesi ve bir çardak, bercife/barcika? ve lorud? ve Bosna Nehri ağzında ve Klakar karşında olan iki tane palanka ve Kobaš, Gradiška ve Yesanofça ${ }^{52}$ diğer adıyla Gradina ve palankaların bazıları Osmanlılar ve bazıları da

and Foreign Powers.1535-1855, s. 109; J. W. Zinkeisen, a.g.e., s. 566.

Tememssükün dördüncü maddesi bkz.: Treaties Between Turkey and Foreign Powers.1535-1855, ss. 110-

111.

43 I. Mažuran, “a.g.m.”, ss. 175-179.

44 Bijeljina.

45 Šabac.

46 Donja Mačva, Gornja Mačva.

47 Gračanica.

48 Tešanj.

49 Banja Luka.

50 Una-Drina nehirleri arasında ve Sava Nehri'nin güneyinde bulunan Uskok Bölgesi.

51 Novy Vetus.

52 Iessenovitz, Jasenovac. 
Habsburglar tarafindan muharebeler esnasında yakılmış ve tahrip edilmiştir. Bu temessük tarihinde bina bulunan ve bulunmayan yerler olduğu gibi Osmanlı İmparatorluğu'na teslim edilecektir. Bekija Kostajnica kazaları kenarından Novi-i Atik Kalesi sınırına varıncaya kadar, palankalarıyla birlikte Osmanlı tarafı ve Sava Nehri içinde olan Ciganlija Adası Belgrad sahilinde olan küçük ada ile Bilya? ve Rahova? arazisine bitişen Orunice diğer adıyla Lima? ve Bosna eyaleti kıyılarına kavuşan Aştina-vezir? adalarına bitiştiği bahanesiyle zabt olunmuştur. Una Nehrinin Sava'ya karıştı̆̆ boğazda Una sahilinde olan Yesanofça diğer adıyla Gradina palankası arazisine kavuşan ada gibi yer de Karlofça Sınırı'nda Osmanlı arazisi olarak tasarruf edilmesinden dolayı yine Osmanlı İmparatorluğu'na ilhak edilmiştir. Keza, Yesanofça Burnundan Una'nın Bosna kıyıları ile Dubica ${ }^{53}$ Kalesi, İslaben ${ }^{54}$, Drinyaçi ve Sofok kuleleri teslim alınmıştır. Novi sınırı öncesi olan Sirovatz Nehri'nin biriktiği yerden karşı Hırvat arazisine geçiş olup, bu küçük yerden itibaren Pasarofça Sınırına göre yeni sınırların belirlenmesi hızlıca başlamıştır. ${ }^{55}$

Bahsedilen geçitten yukarıya doğru Una Nehri içinde olan, Pasarofça sınırına göre Osmanlı sınırları içinde bırakılmış adalar Bosna kıyılarılya birlikte yine Osmanlı İmparatorluğu'nun tasarrufuna bırakılacaktır. Yine Ciganlija Adası'ndan yukarı doğru Sava sahili ile gidildiğinde Una Nehri mesaci? karşısına varıldığında Osmanlı arazisine kavuşmasından itibaren ada tanımlamasına dahil edilmiş ve aslına uygun bir ada olduğu halde Habsburg tasarrufuna bırakılan küçük ve büyük Sava Nehri adalarından Ostružnička ${ }^{56}$ Adası, Zidinska ${ }^{57}$ Adas1, iki parça Kobino Adaları, iki parça Brahova Adaları, bir parça Dargobca Adası, bir parça Uraca Adası ve bir parça Vrbovačka ${ }^{58}$ Adası ve bir parça Diriniç Adası ve Dirina Nehri’nin biriktiği yerden yukarıya doğru gidildiğinde bir parça Račanska Adası, bir parça Bosut diğer adıyla Esna-i Bala ve bir parça Brodska Adası ki toplam küçüklü büyüklü Sava Nehri içinde işte bu bahsedilen on üç ada ${ }^{59}$ karşısında ve İskaladine Yakası ile Una Nehri içinde hudûd olan Sirovatz'ın biriktiği yere varıncaya kadar Karlofca Sınırı dahilinde Habsburgların zaptında olan adalar ve Una Nehri'nin karşı Hırvat sahili ile Coria'ya kadar temessük gereğince Sirovatz geçidinden karşı tarafı Nevbola ve İnce Novink'e karşı Hırvat arazileri Una sahilleri ile birlikte Habsburg tasarrufunda kalmak üzere sınırlandırılmıştır. Kısacası Una Nehri'nin karşısındaki Hırvat tarafında başlangıç humkası olan uçurum kenarında bulunan iki parça karaağaç ve ikinci humka bedeli olan Coria'daki gibi hudûd-1 selâseye kadar olan Pasarofça Sınır humkalarının sağ tarafı Habsburgların ve sol tarafı ise Osmanlıların himayesi ve tasarrufunda olacaktır. Una ve Sava nehirlerine her iki taraftan tecavüzde bulunulmayacak, iki devlet arazisi arasında mu'ayyen olan Coria denilen yere kadar hudûd-ı itibar olduğu dikkate alınarak bahsedilen ortak faydalarda ve iki sahilden yedek şartlar geçerli olacaktır. ${ }^{60}$

\footnotetext{
53 Dubitza.

54 Slabinco.

55 BOA, HAT, 1431-58588, Belge 5, s. 4.

56 Osturyanca.

57 Zeydişka .

58 Urduriçka .

59 Belgrad'dan Sava-Una nehirlerinin birleşme yerine kadar olan nehir adalarının hukuki statüsü için bkz.: Tablo 1.

60 BOA, HAT, 1431-58588, Belge 5, s. 4.
} 
Tablo 1. 1741 Yılında Osmanl1-Habsburg Arasında İmzalanan Temessüke Göre Sava Nehir Adalarının Hukuki Durumu ${ }^{61}$

\begin{tabular}{|c|c|}
\hline Nehir Adasının İsmi & $\begin{array}{l}\text { Tasarruf Edecek } \\
\text { Devlet }\end{array}$ \\
\hline Ciganlija & Osmanlı İmparatorluğu \\
\hline Ostružnička ${ }^{1}$ & Osmanlı İmparatorluğu \\
\hline Zidinska $^{2}$ & Osmanlı İmparatorluğu \\
\hline Podgorička/Kamenička ${ }^{3}$ & Osmanlı İmparatorluğu \\
\hline Karakuška $^{4}$ & Osmanlı İmparatorluğu \\
\hline Vitojevačko Ostr & Osmanlı İmparatorluğu \\
\hline Kupinovac & Habsburg Monarşisi \\
\hline $\mathrm{Krstac}^{5}$ & Habsburg Monarşisi \\
\hline Vrbovačka $^{6}$ & Habsburg Monarşisi \\
\hline Vrtić $^{7}$ & Habsburg Monarşisi \\
\hline Račanska $^{8}$ & Habsburg Monarşisi \\
\hline Donjoštitarska ${ }^{9}$ & Osmanlı İmparatorluğu \\
\hline Štitarska & Habsburg Monarşisi \\
\hline Brodska $^{10}$ & Habsburg Monarşisi \\
\hline
\end{tabular}

3.2. Una Nehri Bölgesinde Osmanlı-Habsburg Hudûdu (11 Mayıs 1741): Sava ve Una Nehirlerinin Birbirine Karıştığı Yerden (Jasenovac Palankası) Hudûd-ı Selâsenin Olduğu Yere (Srb Nahiyesi) Kadar Olan Bölgenin Hudut Tahdidi

\subsubsection{Aşağı Una Sahil Bölgelerinin Sınırları: Sava ve Una Nehirlerinin Birleştiği Yerden} Klepala Dağlarına Kadar Olan Bölgenin Hudut Tahdidi

Una ve Sava nehirlerinin birleştiği boğazdan iki tüfek atışı mesafe içeri girildiğinde yani Jasenovac ${ }^{62}$ Palankası arazisine gelindiğinde, Una Nehri'nin taşması yaklaştığında ada gibi ayrılan nehir adasının Jasenovac arazisine daha yakın olduğu görülmüştür. Bundan dolayı Karlofça Antlaşması sonrasında belirlenen hudut tahdidi sırasında Osmanlı İmparatorluğu'nun teslim aldığı nehir adası misali bu adaya da Karlofça Sınır'ı uygulanmıştır. Daha sonra adı geçen bu nehir adası Jasenovac Palankası'nın yeri ile birlikte Osmanlı arazisi olarak 26 Nisan 1741 tarihinde deftere kaydedilmiştir. ${ }^{63}$

Jasenovac Palankası'ndan yukarıya doğru ilerlendiğinde Novi-i Atik64 Kalesi sınırı olan Sirovatz ${ }^{65}$ Nehri'ne kadar Una Nehri içinde olan nehir adalarının hukuki durumu ise Sava Nehir adalarınınki gibi açıkça belirtilmemiştir. Sadece Belgrat'tan Novi-i Atik'e gelinceye kadar yapılacak hudut tahdidinde Karlofça Antlaşması sonrasında belirlenen sınıra bağlı kalınması kararlaştırılmıştır. Sözü edilen Una Nehir adalarının Sirovatz Nehri’nden aşağıda yer almalarından

\footnotetext{
61 Bu tablonun bilgileri için bkz.: I. Mažuran, “a.g.m. ”, ss. 176-177.

62 Yesanofça, İessenovitz, Jessenowiz, Jassenovicz.

63 BOA, HAT, 1431-58588, Belge 6, s. 4.

64 Novi(y) Vetus, Bosanski Novi, Novi Vára.

65 Esterizine.
} 
ve Karlofça Sınırı'nda bulunmalarından dolayı hukuki durumları Karlofça Sınırı'nda belirlendiği şekliyle kalmıştır. Sirovatz Nehri'nden yukarıda olan ve Pasarofça Antlaşması'ndan beri Osmanlı tasarrufunda bulunan Una nehir adalarının kullanımı ise eskisi gibi Osmanlı İmparatorluğu'na bırakılmıştır. ${ }^{66}$

Jasenovac yakınında olan ada gibi yerin söz konusu palanka ile birlikte Osmanlı hâkimiyetine alınmasından sonra Una Nehri'nin Bosna sahilinden üç saat mesafede ${ }^{67}$ bulunan Dubica ${ }^{68}$ Kalesi Osmanlı egemenliğine girmiş ve içine muhafızlar yerleştirilmiştir. Sonrasında buradan iki saat yukarıda, Una sahilinde bulunan Szlubin ${ }^{69}$ Kalesi'ne geçilmiş ve buradaki değirmenle birlikte kale Osmanlı tasarrufuna alınarak kalenin içine muhafızlar konuşlandırılmıştır. Szlubin'dan bir saat yukarı gidilerek Dernova ${ }^{70}$ Kalesi'ne gelinmiş, kalenin içine bir ağa ve birkaç muhafız; bu yerden yukarı doğru, Kostajnica ${ }^{71}$ yakınında bulunan Sofok ${ }^{72}$ Kuleleri'ne de bir ağa ve birkaç Osmanlı muhafızı yerleştirilmiştir. Sofok Kuleleri'nden iki buçuk saat ilerisinde yer alan Novi sınırına ${ }^{73}$ gelindiğinde Karlofça Sınırı tamamlanmıştır. Novi sınırının yukarısında bulunan Pasarofça Sınırı'nın başlangıç humkası olarak işaretlenmiş karaağaçlara kadar olan Una nehir adaları, Karlofça ve Pasarofça sınırlarına göre Osmanlı İmparatorluğu'nun kullanımında olduğundan dolayı Pasarofça Sınırı uygulanmış ve bahsedilen adaların Osmanlı İmparatorluğu'nun yönetiminde eskisi gibi kalması şeklinde sınır defterine kaydedilmiştir. ${ }^{74}$

Daha sonra Pasarofça sınııının başlangıcı olan Sirovatz Nehri ${ }^{75}$ geçidinden karşıdaki Hırvat arazisine geçilmiş, "Una'dan ileri" diye tabir edilen bu bölgenin hudutları Pasarofça Sınırı'na bağlı kalınarak belirleneceği kararlaştırılmıştır. Geçitten sonra yukarı doğru Una Nehri’nin batı tarafindaki Hırvat sahilleri boyunca dört buçuk saat yürünerek Hırvat arazisinde yer alan Novi-i Cedid $^{76}$ toprağına gelinmiştir. Novi ve Krupa arazileri arasında, Una Nehri kenarındaki uçurumda olan iki parça karaağaç Pasarofça Sınıı belirlenirken muhaddidler tarafından humka karşılığında

66 BOA, HAT, 1431-58588, Belge 6, s. 4. Habsburg Monarşisi’nin bundan önceki hudûd tahdîd çalışmasını yapan muhaddidi Sava sahilinde bulunan yıkılmış palankaların yerlerini antlaşmaya uygun şekilde teslim ettiklerini belirtmiştir. Fakat Sirovatz Nehri'nden yukarı olan ve Pasarofça Sınır'ından beri Osmanlı tasarrufunda bulunan Una nehir adalarının yine Osmanlı kullanımında kalması gerektiğini belirtmemiş. Bu adaların hâkimiyeti Pasarofça Antlaşması'nda Osmanlılara bırakıldığı söylenmemiştir diyerek muhalefet etmiştir. Osmanlı İmparatorluğu bu durum karşısında adı geçen bu adaları tek taraflı olarak, Karlofça Sınırı'nı uygulayarak mevcut durumun devam ettiği şeklide 28 Nisan 1741/11 Safer 154 deftere kaydetmiştir. Bkz.: BOA, HAT, 1431-58588, Belge 6, s. 4.

Bu mesafeler at ile değil yaya yürüyerektir.

68 Dubitza, Dubiza, Dubizza.

69 İslabin, Slabina, Slabin, Islubin.

70 Drenoviça, Drenovza, Drenovacz.

71 Kostaniçe(a), Castanovitz, Castanovicz, Costaniza. Jasenovac-Dubica arası üç saat, Dubica-Kostajnica arası üç saat, Kostajnica-Novi arası beş saattir. Bkz.: BOA. A.\{DVN.DVE.d... / 903, s. 3-4; T. Gökçe, “a.g.m.", s. 84.

72 Sofa.

73 Bosna'dan gelip Una Nehri'ne karışan Sirovatz Nehri, Sava Nehri gelişinde Novi Sınırı olarak kabul edilmiştir.

74 BOA, HAT, 1431-58588, Belge 6, ss. 4-5.

75 Habsburg muhaddidi Sirovatz Nehri'nin geçidinden geçmeyip iki saat aşağıda bulunan Kostajnica Köprüsü’nden geçmiştir. Bkz.: BOA, HAT, 1431-58588, Belge 6, s. 5. 
sınır işaret sembolü kabul edilmiştir. Una kenarından karşı Grabovitza ${ }^{77}$ Deresi'ne yöneldiğinde ise sağ tarafında olan karaağaç Novi arazisinin bitiş noktası olmuş ve Habsburg muhaddidi o ağaca haç resmetmiştir. Osmanlı muhaddidi ise Grabovitza Deresi'nin sol tarafındaki Coria arazisi ve Ravacinde tarafında olan karaağaca ay ve hilal kazımıştır. Daha sonra işaretli olan karaağaçların ortasına bir humka yerleştirilmiştir. Bu humkadan yüz dört adım ileride bulunan Aşurı Noyol/ Topol tarlasında bulunan yüksek boylu kavak ağacının da etrafı temizlenerek eskisi gibi ikinci humka bedeli olmak üzere Osmanlılar tarafindan sınır işareti olarak bir ay ve hilal, Habsburglar tarafından ise bir haç kazılmıştır. Sonrasında tarlalıkların ötesinde bulunan yoldan geçilip başlangıç oktasındaki bayıra gelinmiştir. Grabovitza Deresi'nin sol tarafından yol aşırı tahminen elli adım mesafede bulunan başlangıç bayırının başında meşelik içindeki meşe ağaçları ayrılmış ve bir pelit ağacı etrafına konulmuş humka yenilenmiştir. Bu humka, Noyol/Topol ağacından sonra üçüncü humka olduğu açıkça belirtilmiştir. ${ }^{78}$

Buradan dik bayırda cadde yol ile kuru kirazları geçip bir süre gittikten sonra üç yolun bir araya geldiği yerde orman içinde ve üç yol ortasında bulunan pelit ağacının etrafında olan iki humka yerinde bırakılmıştır. Bununla birlikte yolun sağ tarafındaki bir büyük pelit ağacı dördüncü sınır işareti olarak kabul edilerek üzerine Osmanlılar kendi tarafına minare işareti kazırken, Habsburglar kendi taraflarına bir haç işareti resmetmiştir. Sonrasında sağ tarafa doğru ilerleyerek Klepala ${ }^{79}$ Bayırı'nda bulunan ve sağ tarafında Habsburg Guazdansky ${ }^{80}$ Kalesi ve sol tarafında Osmanlı Buz(s)in Kalesi arazilerinin bulunduğu eski humka; bu humkanın ilerisinde, yol üzerinde bulunan humka; oradan Radowich ${ }^{81}$ bayırına giderken Chorna Jamnicza ${ }^{82}$ yerlerinde yolun sağ tarafinda kalan humka; ve sonrasında klanacdaki ${ }^{83}$ (derbent) tozağaçı yakınında, yolun sol tarafında bulunan humka yenilenmiştir. Bilâhare yine Radowich toprağında olan Dabrina ${ }^{84}$ Deresi'nin yarısında, eski yol üzerindeki humka; sonra Radowich Bayırı'nın tepesinin solundaki humka; daha sonra Radowich Bayırı'ndaki yolun sağında bulunan humka -solunda Dabrina Deresi bulunan- yerinde bırakılmıştır. Sonrasında Radowich Bayırı başında, yolun solunda bulunan humka; bu humkanınn ilerisinde yer alan Jamnick Bayırı'nın başındaki humka ve yine bahsi geçen Jamnick'in solunda bulunan Ergiavacz ${ }^{85}$ denilen gölün yakınında bulunan humka yenilenmiştir. ${ }^{86}$

Ergiavacz Gölü yakınında bulunan humkadan ilerleyerek Duorcza ${ }^{87}$ Bayırı başını çevreleyen Ceve ve Lubina ${ }^{88}$ suları arasındaki iki yol arasında bulunan bir humka; sonra Jelovagora ${ }^{89}$ denilen mevkide yolun sağ tarafında bulunan humka; sözü edilen yerden ilerleyerek Buz(s)in Kalesi'nin

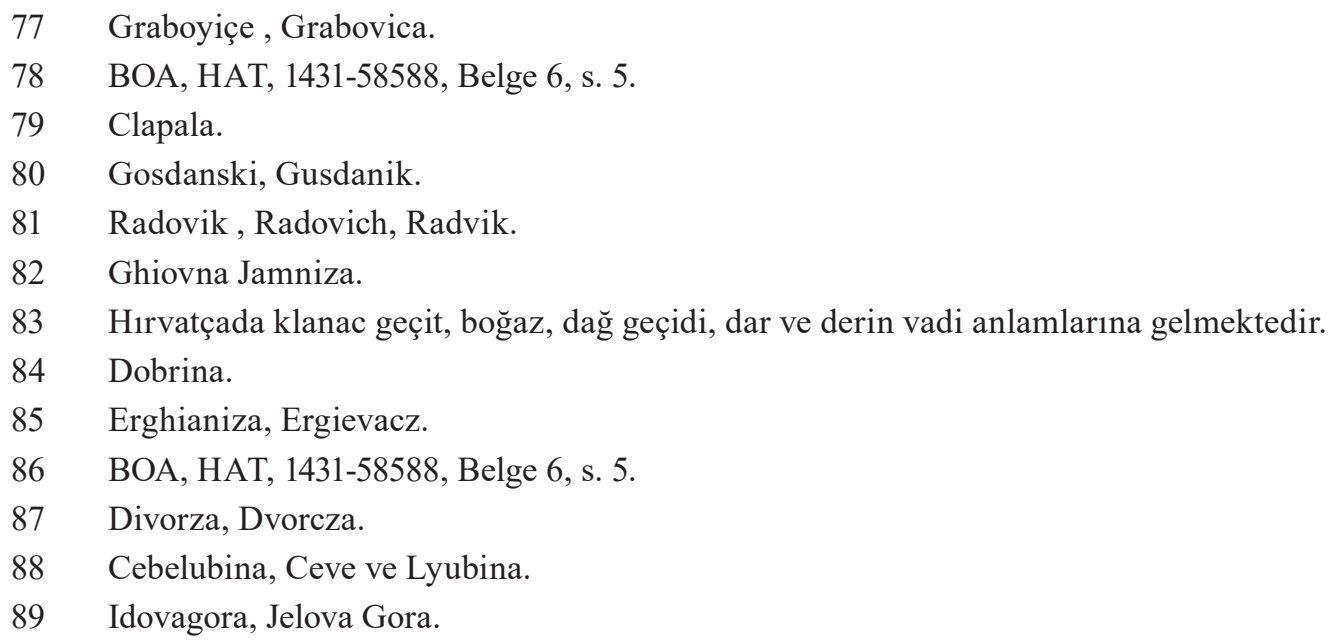


karşısındaki Metle isimli yerde, yolun sol tarafinda bulunan humka yerinde bırakılmıştır. Sonrasında Buz(s)in ve Guazdansky ${ }^{90}$ yolların buluştuğu yerde, yolun sağında Bukofklanza'daki ${ }^{91}$ humka; ardından Nicolina Klanacz ${ }^{92}$ Bayırı başındaki iki yolun arasında bulunan humka; sonra Nicolina Kossa ${ }^{93}$ denilen yolun sağ tarafinda bulunan humka; daha sonra Nicolina Kossa Deresi'ne yakın bulunan humka yenilenmiştir. Dere geçildikten sonra yol ile sınır olmak üzere, Radasticza94 Deresi'nde, yolun sağ tarafında olan humka; arkasından Radasticza Deresi'nden çıkıldıktan sonra Grabauza ${ }^{95}$ Pınarı yakınında, yolun sol tarafinda bulunan humka; oradan Radagka Rabnincza ${ }^{96}$ adlı yerde, yolun sol tarafinda olan humka ve sonrasında Starastrabenicza ${ }^{97}$ diğer adıyla Gunefza ${ }^{98}$ adlı yerde yolun sol tarafında bulunan humka yerinde bırakılmıştır. Sözü edilen yerden ilerleyerek, Radonicha Klavicza ${ }^{99}$ Bayırı'nın sağındaki Jassenov Potok humkası; sonrasında Babiga Klavicza ${ }^{100}$ Bayırı'nın solunda olan ve Kobe Hraste denilen kadîm humka yenilenmiş̧ir. Arkasından Verch Platina ${ }^{101}$ Deresi yakınında ve Verstov Potok ${ }^{102}$ diğer adıyla Boyore Yone Lofoh denilen yerde, yolun sol tarafında bulunan humka; sonra Vrcboca Bolada Behlu Kossa denilen bayırda yüksek bir ağaç etrafında olan humka; daha sonra Graboce diğer ismiyle Gerlewicz ${ }^{103}$ Bayırı'nda, Regiebouza 104 humkasının tam karşısında fazla "karantılık?" arasında açık yerde bir meşe ağacı etrafında bulunan humka yerinde bırakılmıştır. Karşı karşıya olan dağların arasında olan bu yer, kadimî hudûd olup her iki tarafın arazisini birbirinden ayırmıştır. ${ }^{105}$

Sözü edilen kadimî huduttan temyiz edilecek Oskorus ağacina doğru ilerlendiğinde, ağacın yıkılmasından dolayı etrafında olan humka yerinin yeniden belirlenmesi gerekmiştir. Humkanın yeni yerinin belirlenmesinde şüphenin giderilmesi için her iki tarafin ihtiyarlarına başvurulmuş; ihtiyarlar ise değiştirmeksizin ve bozmaksızın ortada bulunan kadîm Broş ve Goznevaç potoklarının eskiden beri gözle görülür işaret olduklarını bildirmişlerdir. Bilâhare Prestoua ${ }^{106}$ Suyu ile Boina ${ }^{107}$ Deresi hudûd olmak üzere karşılı̆̆ında Brdo ağacı çevresinde olan humkanın etrafında olan ağaçlar kırdırılıp temizlenmiş ve yenilenmiştir. Sözü edilen yerden ilerleyerek sırasıyla Boinaskyn humkası, Çerkoyna humkası ve oradan Rodine denilen (?) eşit yakınlıkta bulunan humka, Badrik humkası,

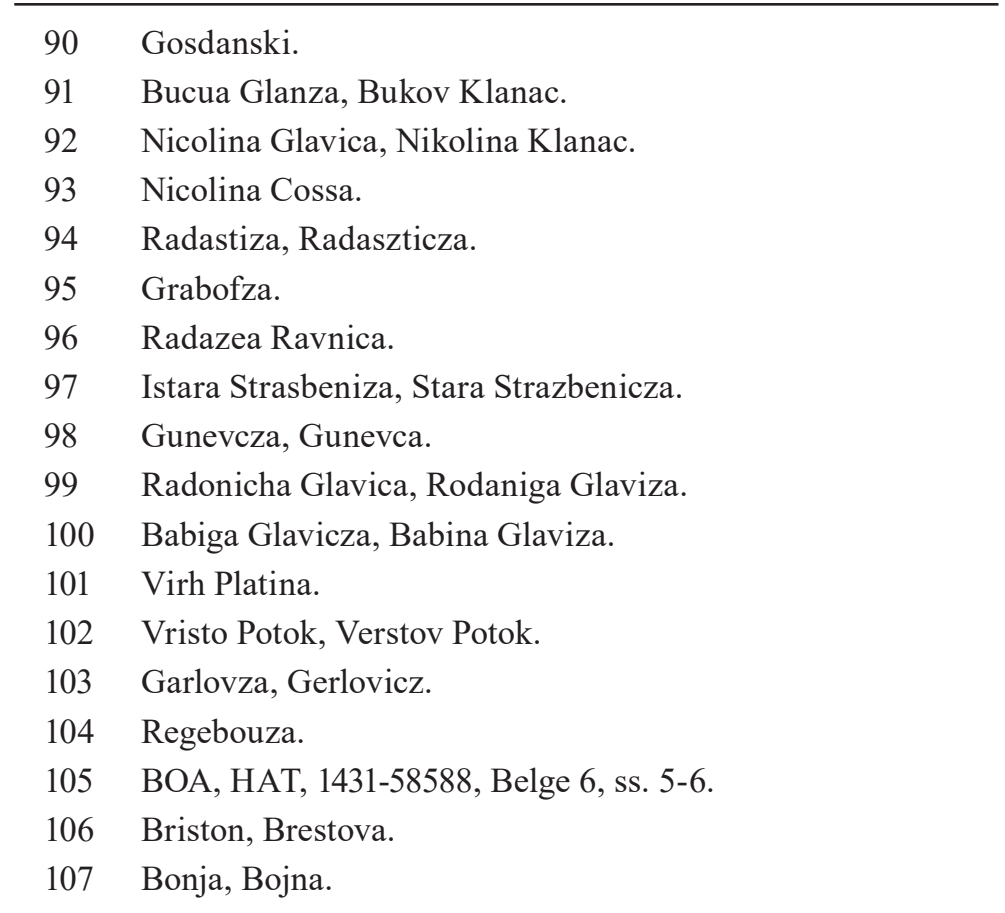


Zebteni Nice humkası, Lest(n)ik denilen yerde bulunan humka, Boinik ${ }^{108}$ Kalesi harabesi içerisinde olan humka, Luriasticza ${ }^{109}$ Deresi karşısında iç tarafta bulunan humka ve buraya yakın Kolon ${ }^{110}$ Bayırı'ndaki pelit ağacının etrafında bulunan Müsnedam Ağa humkası yerlerinde bırakılmıştır. Yine buraya yakın yerde yolun sağ tarafında Kör A ğazade humkası; sonrasında Crnbouka Deresi yakınında ve yolun sağ tarafında bulunan İstava Loşaniha humkası; buradan Chihaga Kossa ${ }^{111}$ Bayırı'nda bir humka; oradan yine Chihaga Kossa Bayırı'nın başında, yolun sağında ve Yerzi Kaya denilen humka yenilenmiştir. Bilâhare yine Chihaga Kossa'da bir işaretli ağaç yakınında bulunan humka; sözü edilen yerden Cemerniza ve Bacota ${ }^{112}$ derelerinin birleştiği yerde olan humka; sonrasında Joanis ${ }^{113}$ Potoğu'na gelirken yolun sol tarafinda bulunan humka ve oradan Joanis Kossa ${ }^{114}$ Bayırı'nda bir humka yerinde bırakılmıştır. Böylece Buz(s)in Kalesi'nin hudûdu tamamlanmıştır ${ }^{115}$

\subsubsection{Glina-Gliniza Nehirlerinin Birleşmesinden Korana Nehrine Kadar Olan Bölgenin Hudut Tahdidi}

Podsvize ${ }^{116}$, Kladuş ${ }^{117}$ ve Cetin kaleleri arazilerinin sınırının açıklanmasına gelince ise; Glina ile Rabina'nın ${ }^{118}$ birleştiğ ${ }^{119}$ yerin aralığında olan eski humka ortasında ortaya çıkan bir parça elma ağacından başka etrafinda olan ağaçlar kesilmiş, temizlenmiş ve yenilenmiştir. Oradan Rabina nehirciği Pasarofça sınırı itibârı ile (...?) kaynağı başından Krantılık Ovası'nda bir kesik $\operatorname{gurab}^{120}$ ağacı etrafında olan taşlıca humka yerinde bırakılmıştır. Sonrasında Grabovza Bayırı'ndan ilerleyerek Habsburg toprağı olan çardak yakınındaki yokuş başında Ormanik Ovası'nda kesilmiş bukva ağacı çevresinde olan humkanın etrafı temizlenmiş ve her iki tarafça işaretlenmiştir. Söz edilen yerin sol tarafında (...?) içinde olan humkanın etrafı temizlenmiştir. Buradan dik yukarı dere ile ilerleyerek başta (...?) hizmeti olan humka yenilenmiştir. Oradan Grabovza Deresi'nin iniş bayırının yarısında pelit ağacı etrafında Cetiriovo Bilo'da birlikte olan humka yerinde bırakılmış ve ağaç işaretlenmiştir. Bilâhare düzlükteki Krsova Kosası'nda bir büyük gizli/kapalı humka; oradan Kirladusa ${ }^{121}$ Potogu başındaki humka; buradan Kirladusa denilen potokta bulunan humka ve oradan Gnoinicza ${ }^{122}$ Bayırı başında kökünden çıkıp yıkılmış armut ağacı bitişiğindeki eski humka yenilenmiştir. Buranın arka tarafına doğru gidilince yakın bir yerde olan bir humka; buranın aşağısındaki luğ içinde olan humka yerinde bırakılmıştır. ${ }^{123}$

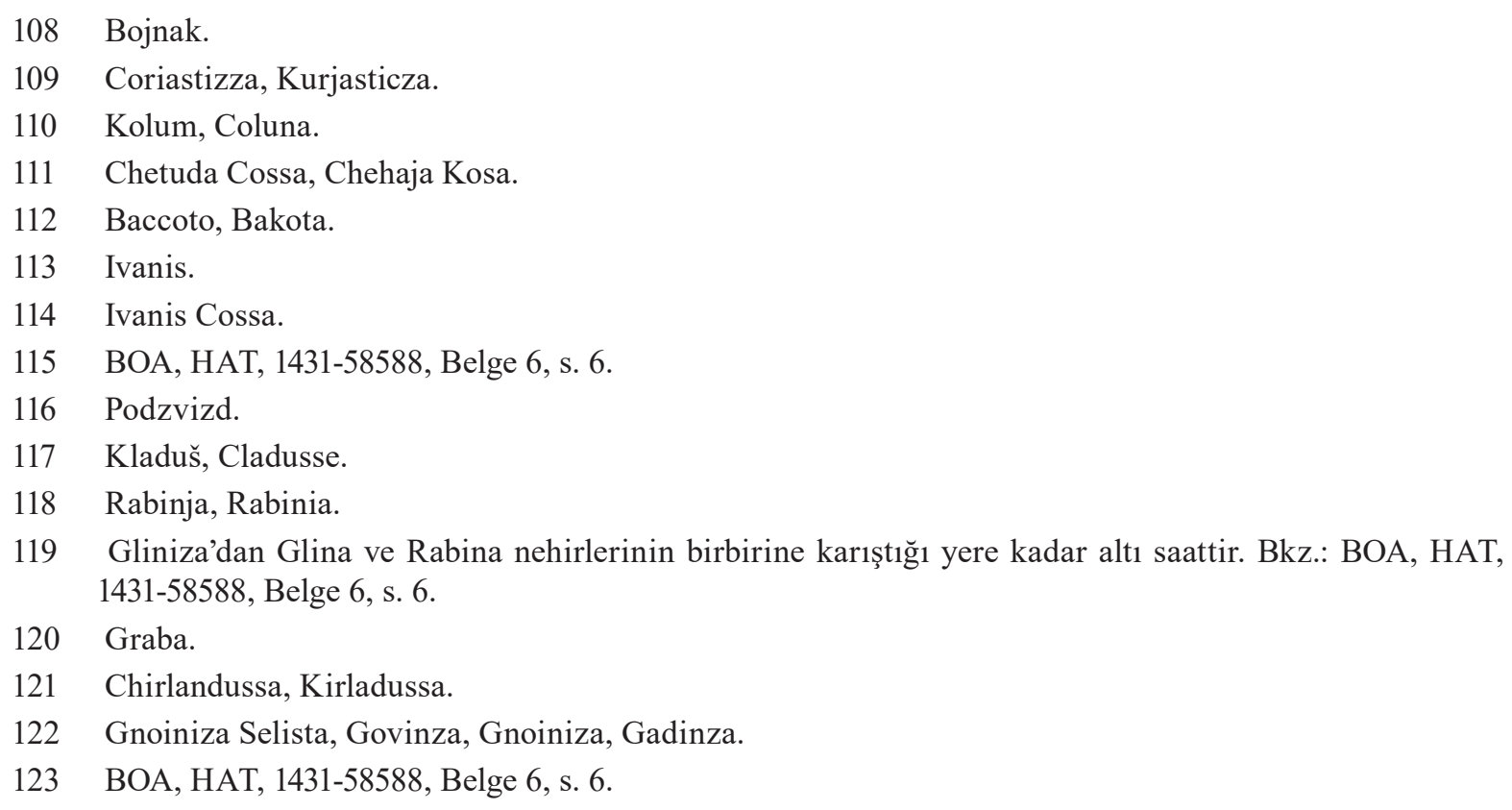


Gnoinicza Nehir arazisinin sona erdiği ve Korona Nehri'ne döküldüğü yer olan Lonah'da bulunan humka hudûd-1 i’tibar olarak kabul edilmiştir. Sklop ${ }^{124}$ geçiti ötesi Stari Prututz ${ }^{125}$ Kalesi tarafindaki Korona Nehri'nin yukarısına yarım saatten fazla mesafede olan Habsburg zabtında olan ada karşısındaki Rastuk başında olan jasen ağacı etrafında olan humka yerinde bırakılmış ve ağaç her iki tarafça işaretlenmiştir. Zapolka'ya ${ }^{126}$ giderken luğlar içinde ırmak başındaki humka; oradan yine Zapolka'ya giderken loğ içinde bir dal pelit ağacı etrafında olan humka; sonrasında luğların sonunda Zapolka yakınında bir çatal gurab ${ }^{127}$ ağacı etrafinda olan taşlıca humka yenilenmiştir. Oradan Kazpolka sonunda olan harabe kiliseden ilerideki meşelik bitişiğindeki büyük pelit ağacı etrafında olan humka yerinde bırakılmış ve ağaç ay ile işaretlenmiş̧tir. Buranın dik yukarısında Masvina ${ }^{128}$ Yaylası doruğunda bir bukva ${ }^{129}$ ağacı etrafında olan humka; sonrasında Masvina Yaylası sırtı ile Horian Kalesi karşısındaki bukva ağacı etrafında olan humka; buranın dik aşağısındaki Rudeniy Kopoliz'e' ${ }^{130}$ giderken mermer taş ile doldurulmuş çukurların arasında bulunan bir büyük pelit ağacı etrafında olan humka; aynı yerde bulunan düzlükteki çukurlar ovasında yanmış bir pelit ağacı etrafinda olan humka yenilenmiştir. Bilâhare yine bahsedilen Rudeniy Kopoliz'de bir çukurcukta bir pelit etrafinda olan humka ve oradan Rudeniy Kopoliz'de olan eski humkalar karşısında olan humka; sözü edilen yerden aşağıda düzce bir yerde bulunan yanık ve kuru pelit ağacı etrafında olan humka yerinde bırakılmıştır. Yanmış ağacın yakın zamanda büsbütün yok olacağ bellidir. Horian131 Štorlic ${ }^{132}$ ve Tržac ${ }^{133}$ kaleleri hududu burada tamamen ayrılmıştır. ${ }^{134}$

Sonrasında bahsedilen Verch Rudeniz Kopolie'de iki çatal pelit ağacı etrafında olan humka; oradan Plisniza ${ }^{135}$ Dağ 1 ile Rudeniz ${ }^{136}$ Ovas1 arasındaki pelit ağacı etrafında bulunan humka; ve buradan Plisniza'nın altında yol üzerinde olan humka yenilenmiştir. Bu yerden Plisniza denilen bayırın doruğunda bir pelit ağacı etrafında bulunan humka; oradan Plisniza altındaki Delli Bassin Razchoi ${ }^{137}$ denilen yerde olan humkayerinde bırakılmıştır. Sonrasında devam edilerek Lumbardenik ${ }^{138}$ kule yolu ötesine geçilerek Razovizenski ${ }^{139}$ Ovası'nda bulunan humka; buradan Küçük potoğun ${ }^{140}$ geçtiği yerdeki düzlükte olan humka; oradan Rakoviza Potoğu'nun ${ }^{141}$ üst tarafındaki humka yenilenmiştir. Aynı yerdeki Bunar/Pınar çeşmesinden her iki tarafında yararlanması konusunda

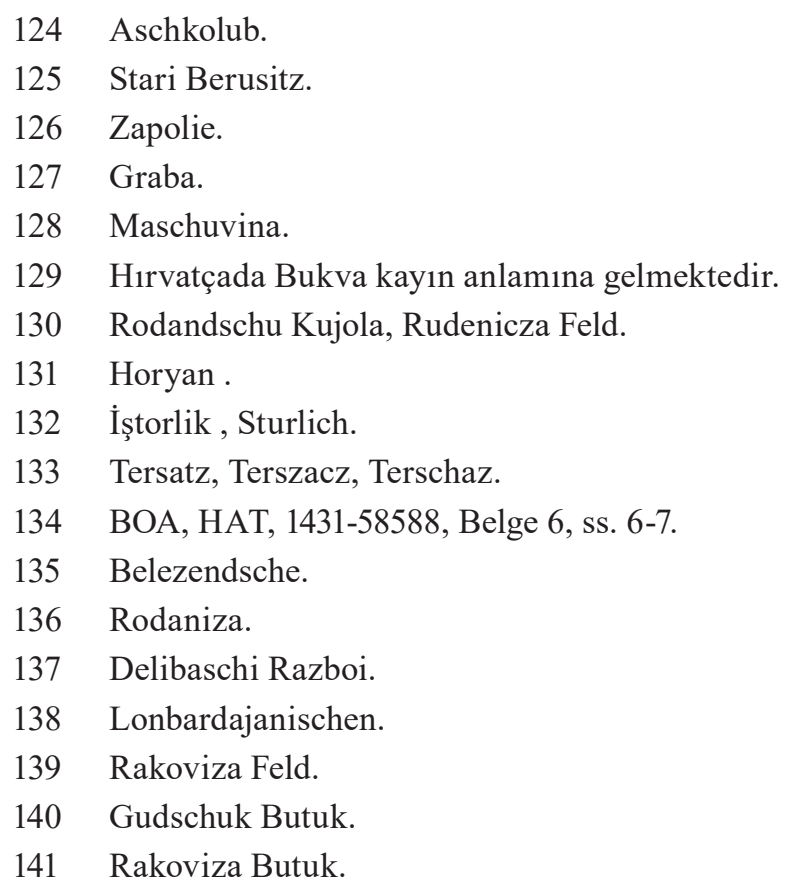


muhalefet edilmemesi için daimi bir sözleşme yapılmıştır. Bahsedilen bu potok sümün/sümn sâât ${ }^{142}$ miktarı huduttur ve ötesinde olan bayır üstündeki pelit ağacı etrafında olan humka; sonrasında yol kenarındaki düzlükte olan pelit ağacı etrafındaki humka; daha sonra Crabouza ${ }^{143}$ kaynağının üst tarafındaki bayır başındaki küçük pelit ağacı etrafındaki humka yerinde bırakılmıştır. Crabouza'nın üst tarafındaki pelit ağacı etrafinda olan ve bahsedilen Plisniza Dağı ile Crabouza kaynağı arasında Şarzadol'a ${ }^{144}$ yakın yerde olan humka; sonra Cebel Ovası'nda, eskiden her iki tarafin vekilleri tarafından bahsedilmiş yolun sol tarafında bulunan çatal kavak ağacı etrafindaki humka yenilenmiş ve her iki taraf kendi sınır işaretini kazımıştır. Sözü edilen yerden ilerleyerek Şarzadol yakınında bulunan koz/kavak ağacı etrafındaki humka; buradan kadim yolun sol tarafında, Runiaviza Yaylası karşısında iki çukur arasında yakılmış ve yıkılmış breze ${ }^{145}$ ağacı etrafındaki humka; sonra Runiaviza Yaylası'nın alt tarafındaki iki çukur arasında pelit ağacı etrafındaki humka; daha sonra Korona'nın üst tarafındaki Değirmen Geçidi (Melinarki Brod) denilen yol altındaki yerin yanındaki çukur yerde bulunan humka yerinde bırakılmıştır. Korona'nın Una tarafındaki zikrolunmuş kalelerin kadimi arazileri yukarıda ayrıntılarıyla açıklandığı üzere eksiksiz tekerrür edilmiştir. ${ }^{146}$

\subsubsection{Yukarı Hırvatistan'ın Hudutları: Jeszera'dan Hudûd-ı Selâseye Kadar Olan Bölgenin Hudut Tahdidi}

Korona Nehri'nin Osmanlı tarafındaki Plessivicza Yaylası'nın karşısında bulunan Drežnik ${ }^{147}$, Izacić $^{148}$ ve Bihać ${ }^{149}$ kalelerinin mukâbilinde olan yaylaların sırtındaki humkaların yerleri tüm ayrıntıları ile açıklanmıştır. Buna göre ilk olarak Korana Nehri geçilip Plessivicza Yaylası'nda Korona'nın kaynağı olan Jestera'ya bakan Pugliadele denilen bayır başındaki muvakkate (geçici) ağacı etrafındaki humka yenilenmiştir. Oradan bahsedilen yayla sırtı ile Izacić Kalesi karşısında ve J(Y)alva Yolu üzerinde Nakoprivita Kossa denilen yerdeki humka; bilâhare yine aynı yaylanın sırtı ile Vraseverch yolunda ve Naverch Plessivicza'da bulunan pelit ağacı etrafındaki taşı humka yerinde bırakılmıştır. Sözü edilen yerden yine aynı yayla sırtıyla ilerleyip Farkaschiez yolunun ortasında Niloha karşısında bulunan bir humka yenilenmiş, adı geçen kalelerin humkaları da bahsedilen yerde tamamlanmıştır. ${ }^{150}$

Odwina $^{151}$ Kulesi ve Lapatz ${ }^{152}$ Çiftliği Kulesi, Borigovacaz ${ }^{153}$ Kalesi harabeleri, Ostrowiz ${ }^{154}$ Kalesi, Una büyük nehir Köprü Palankası (Palanka-i Vakf-ı Una) serhadlerinin arazileri karşısında olan yaylaların sırtlarıyla ayrılan sınır humkaları açıklanmıştır. Bunun üzerine, Farkaschiez yolu humkasından yine bahsedilen edilen yaylanın sırtıyla ilerleyerek Verch Kuk Yaylası'na gelindiğinde

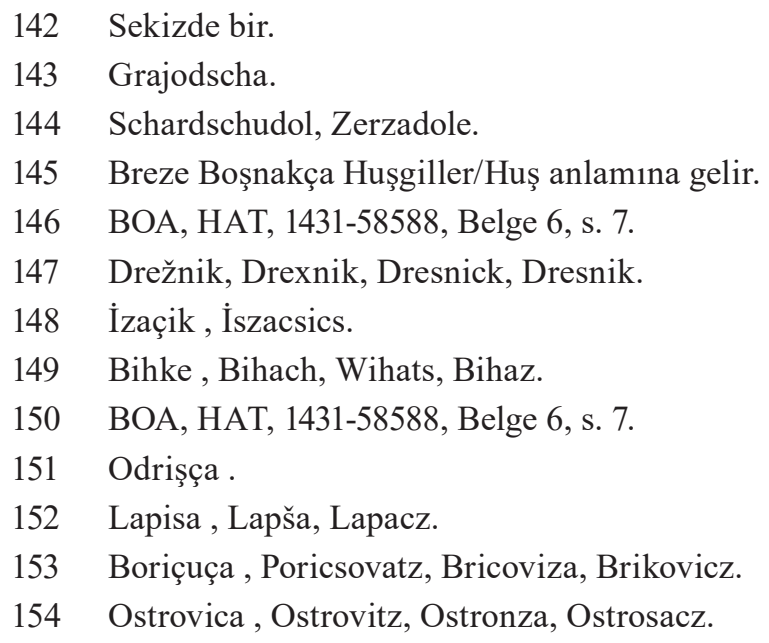


yol üzerinde Klupa yakınında çatal gurab ağacı etrafındaki taşlı humka onarılmıştır. Oradan yine sirt ile ilerleyip Massin ${ }^{155}$ Yaylası'nda olan Vissokaloqua isimli yerde bulunan humka; sonra yine yaylaların sirtı ile ilerleyip Lumbardinik yolunda Dugo Palina isimli yerde olan humka; daha sonra Gradovita Kossa ile Velikilizaz isimli yerde bulunan humka yerinde bırakılmıştır. Bahsedilen yerdeki serhaddin karşısındaki hudutlar böylece eksiksiz tamamlanmıştır. ${ }^{156}$

$\mathrm{Srb}^{157}$ Nahiyesi hudûdunun humkalarını açıklanmıştır. Bu bağlamda, Velikilizaz humkasından ilerleyerek Cemerniza Yaylası doruğunda olan bunar /pınar yakınındaki humkaya gelinmiş ve yenilenmiştir. Bunardan /pınardan her iki tarafın da faydalanması ve birbirine muhalefet etmemesi üzerine nizam verilmiştir. Sonrasında Cemerniza Yaylası'ndaki Dabaristicza doruğunda yolun sol tarafındaki humka yerinde bırakılmıştır. Cemerniza Yaylası sonundaki Kupirucha denilen köye bakan bayır doruğunda Yrlokoba üzerinde el ayası yazması gibi kadimi nişan ile france olarak ifade edilen bedel-i humka özelliği ve vaziyeti üzere evvelki halinde bırakılmıştır. Zstraszbenicza da denilen Srb Nahiyesi'ne bakan doruktaki humka yerinde birakıldı. Sonrasında Papine Klanac başında yolun sağında bir büyük ağaç etrafinda olan taşlı humka yenilenmiştir. Buranın dik yukarısındaki Popistak Yaylası tepesine doğru olan bir dolanı çıplak bayırın üzerindeki humka; sonra Popistak Yaylası'nda bir yüksek taşlı üzerindeki humka yerinde bırakılmıştır. Bu iki humka birbirinden görünmektedir. Bilâhare yine Popistak Yaylası sırtından dümdüz gidilirken Korina Deresi ve kuyuları sağ tarafta kalıp Küçük Popino’ya beraberinde varıldığında tam Küçük Popino'ya karşı bahsedilen yaylanın (Popistak) yüksek bir yerinde olan humka yenilenmiştir. Buranın ilerisinde sağ tarafta, Rauna Popistak denilen taşlı tepenin üzerinde bulunan, dört tarafa bakan humka yerinde bırakılmıştır. ${ }^{158}$

Srb nahiyesinden Una Hırvatlık tarafina geçildiği zaman, Popistak Yaylası'nın sonunda olan dört tarafa nazır humkadan dik aşağıya doğru Zidchaf Dol'dan Venedik tarafına giden yolun solundaki Bobia Bayırı dibinde bulunan Nerumkâ olarak bilinen kadim humkanın bulunduğu yer hudud-1 selâse mevkisi olmasından dolayı bu bölge, üç devletin muhaddidleri tarafından birlikte tahkik edilerek ve birbirlerine onaylatarak fikir birliği çerçevesinde kararlaştırılmıştır. Buna göre sağ tarafta olan taş humka Habsburgların ve sol tarafta olan sanat ürünü büyük taş humka Osmanlıların ve ilerideki humka Venediklilere ait olduğu kabul edilmiştir. İște bu şekl-i melsde bulunan üç parça atik humkaların ortasına iki zirâ' mikdarı boyunda ve sağ taştan olmak üzere yeni baştan konulmuş ve yapılmıştır. Tevfik-i hak ve pür-ü red kâr-ı mutlak ile adı geçen yerde emir yazılarak tamamlanmış ve sağlamlaştırılmıştır. Osmanlı kalelerinden Novosel kazasında olan atik Ostrowiz ve Habsburg büyük kaleleri arazilerine bitiştiğinde ise monarşi taraflarından Zvonigrad159 Kalesi arazisine ulaşmış ve Venedikli tarafindan Plavno Kalesi arazisine ulaşmış olduğundan zikredildiği üzere tüm tefrik/ayırma ve temyiz/ayrılma gerçekleşmiştir.160

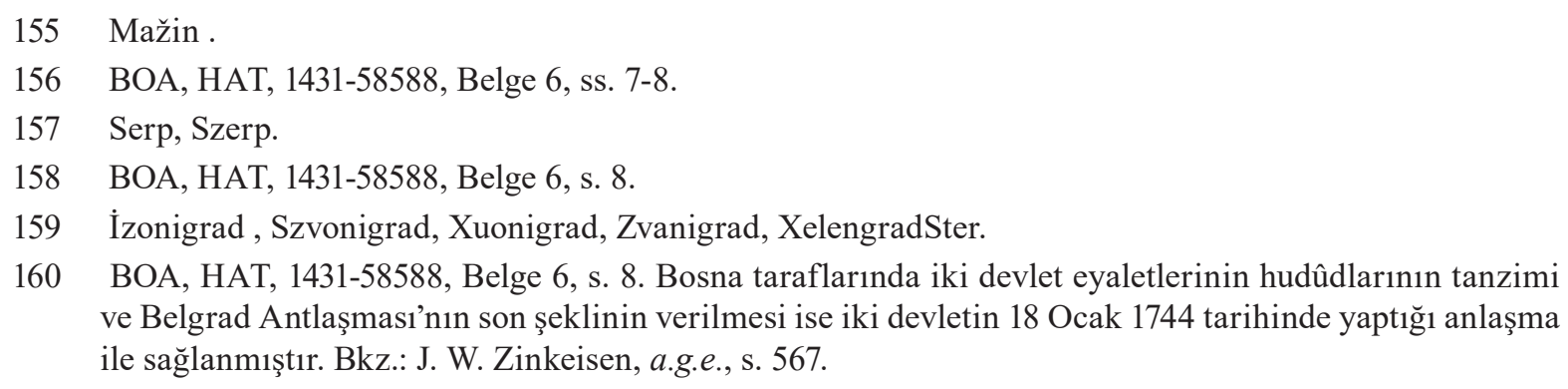

160 BOA, HAT, 1431-58588, Belge 6, s. 8. Bosna taraflarında iki devlet eyaletlerinin hudûdlarının tanzimi ve Belgrad Antlaşması'nın son şeklinin verilmesi ise iki devletin 18 Ocak 1744 tarihinde yaptığı anlaşma ile sağlanmıştır. Bkz.: J. W. Zinkeisen, a.g.e., s. 567. 


\section{Sonuç}

Yukarıda tasvir edilmeye çalışılan Osmanlı-Habsburg sınır hattının belirlenmesi konusunda bulunan defterin dördüncü, beşinci ve altıncı belgeleri, bize iki siyasal gücün arasındaki hudutların doğal olarak Una ve Sava nehirleri olduklarını göstermektedir. Her ne kadar Belgrad Antlaşması'nın yedinci maddesi Una ve Sava bölgesindeki hudutları belirtmiş olsa da, antlaşma sonrası bu nehirlerin hudutları ne kadar belirleyeceği konusunda ihtilaflar ortaya çıkmıştır. Bu bağlamda 2 Mart 1741 tarihinde varılan anlaşmaya göre Sava ve Tuna nehirlerinin birleştiği yerden, Una'nın Sava’ya karıştığ1 yere kadar, oradan Novi-i Atik Kalesi'nin olduğu yere kadar Karlofça sonrası oluşan hudut kapsamında; Una Nehri'nin karşısında Novi-i Cedid Kale bölgesinden hudûd-ı selâseye kadar Pasarofça sonrası oluşturulan hudut esas alınarak düzenlenmesi kararlaştırılmıştır. Böylece Drina Nehri'nden yukarı Bosna tarafında iki siyasal gücün sınırı Sava ve Una nehirleri olmuştur. 1741 tarihli temessük, Sava ve Una nehirleri için ayrı ayrı kurulmuş olan tahdîd-i hudûd komisyonlara gönderilmiş ve sınır hattının kesin belirleme çalışmaları başlamıştır. Yapılan çalışmalar sonucunda Sava nehri üzerindeki on üç nehir adacıklarının hukuki durumu netleşirken, Una Nehri bölgesinde Jasenovac Palankasının, Novi-i Atik, Çetin, Kladuš, Poricsovatz, Ostrovica kale arazilerinin, Lapatz Çiftliğinin ve Srb Nahiyesinin sınır hatları keskin bir şekilde belirlenmiştir. Bosna'da, Una ile Drina arasında ve Sava'nın güneyinde bulunan, Uskok Bölgesi olarak isimlendirilen dar bir toprak şeridi Osmanlı'ya verilmiştir. Sonrasında yeni sınır, Sava boyunca ilerleyerek Una'nın birleşme noktasına gelerek buradan Una boyunca ilerleyip Novi-i Atik'e ulaşmıştır. Bu yerden Una Nehri'nin karşısına geçip Novi-i Cedid Kalesi'nden başlayarak Žirovac Deresi/Çayı boyunca ilerleyerek Bojna Köyü üzerinden hudûd-1 selâseye gelmiştir. Böylece iki taraf, arazilerini sistematik bir şekilde açıkça tanımlanmış doğrusal bir sınırla ayırmıştır. Bu sınır hattı Habsburg Monarşisi'nin bundan sonraki iki yüz yılı boyunca, I. Dünya Savaşı sonunda Avusturya-Macaristan İmparatorluğu'nun çöküşüne kadar değişmeyecektir.

\section{Kaynaklar}

\section{Cumhurbaşkanlığı Osmanlı Arşivi}

BOA, HAT, 1431-58588.

BOA. A.\{DVN.DVE.d.../ 903.

BOA, Nemçelü Ahidnâmesi, 59/3.

\section{Araştırma ve İnceleme Eserleri}

Abou-El-Haj, Rifa'at. A. "Ottoman Diplomacy at Karlowitz", Journal of the American Oriental Society, 1967 (87/4), ss. 498-512.

Abou-El-Haj, Rifa at. A. "The Formal Closure of the Ottoman Frontier in Europe:1699-1703”, Journal of the American Oriental Society, 1969 (89/3), ss. 467-475.

Aksan, Virginia H. "Austro-Ottoman War (1736-1739)", The Encyclopedia of War, (Ed.) Gordon Martel, Chicester: Wiley-Blackwell, 2012, ss. 1-3.

Aksan, Virginia H. "Savaş ve Barış", Türkiye Tarihi: Geç Osmanlı Imparatorluğu 16031839, C. III, (ed.) Suraiya Faroqhi, (çev.) Fethi Aytuna, İstanbul: Kitap Yayınevi, 2011, ss. 109152. 
Aksan, Virginia H. Kuşatılmış Bir İmparatorluk: Osmanlı Harpleri 1700-1870, (çev.) Gül Çağalı Güven, İstanbul: Türkiye İş Bankası Kültür Yayınları, 2. Baskı, 2011.

Angeli, Major Moriz von. "Der Krieg mit der Pforte, 1736 bis 1739", Mitteilungen des k.k. Kriegsarchivs (1881), ss. 247-298, 409-79.

Caporaso, James A. "Changes in the Westphalian Order: Territory, Public Authority and Sovereignty.”, International Studies Review, 2000 (2/2), ss. 1-28.

Diener, Alexander C. \& Hagen, Joshua. Borders: A Very Short Introduction, Oxford: Oxford University Press, 2012.

Doğan, Güner. "Venediklü ile Dahi Sulh Oluna": 17. ve 18. Yüzyllarda Osmanll-Venedik İlişkileri, İstanbul: İletişim Yayınları, 2017.

Đurđev, Branislav. "Bosna Hersek", TDV İslâm Ansiklopedisi, C. VI, İstanbul: Türkiye Diyanet Vakfi Yayınları, 1992, ss. 297-305.

Gökçe, Turan. "1699-1700 Tarihli Bosna Vilâyeti Hududnâmesi", Tarih İncelemeleri Dergisi, 2001 (XVI), ss. 75-104.

Gökçe, Turan. "1699-1700 Tarihli Bosna Vilâyeti Hududnâmesi", Tarih İncelemeleri Dergisi, Say1: XVI, (2001), ss. 75-104.

Karagöz, Hakan. "Belgrad-1 Dârü'l-Cihâd'da Osmanlı Hâkimiyetinin Yeniden Tesisi (1739)", Güney-Doğu Avrupa Araştırmaları Dergisi, 2018 (33), ss. 183-205.

Karagöz, Hakan. 1737-1739 Osmanll-Avusturya Harbi ve Belgrad'in Geri Alinmasl, Doktora Tezi, Süleyman Demirel Üniversitesi Sosyal Bilimler Enstitüsü, Isparta, 2008.

Kohn, George Childs. Dictionary of Wars, London \& New York: Routledge, 2013.

Kruhek, Milan \& Pavlović, Augustin. "Granice Republike Hrvatske u svjetlu Karlovačkog (1699) i Požarevačkog (1718) Mira”, Croatica Cristiana Periodica, 1991 (28/15), ss. 105-138.

Kruhek, Milan. "Granice Hrvatskog Kraljevstva u Međunarodnim Državnim Ugovorima. (Od Mira na Žitvi 1606. do Mira u Svištovu 1791.)”, Povijesni Prilozi, 1991 (10), ss. 37-79.

Kurtaran, Uğur. "Ottoman-Austria Border Determınation Works and Newly Determined Borders According to the Treaty of Belgrade of 1739", Belgrade 1521-1867, (Ed.) Dragana Amedoski, Belgrade (2018), ss. 169-193.

Kurtaran, Uğur. "Pasarofça Antlaşması'na Göre Yapılan Sınır Tahdit Çalışmaları ve Belirlenen Yeni Sınırlar”, Uluslararası Sosyal Araştırmalar Dergisi, 2018 (11/55), ss. 285-300.

Kurtaran, Uğur. Osmanlı Diplomasi Tarihinden Bir Kesit: Osmanlı Avusturya Diplomatik İlişkileri (1526-1791), İstanbul: Ukde Yayınları, 2009.

Matuz, Josef. Osmansko Carstvo, Zagreb: Školska Knjiga, 1992.

Mažuran, Ive. "Razgraničenje Između Carske Austrije i Osmanskog Carstva od Utoka Save u Dunav do Novog na Uni 1741. Godine", Anali Zavoda za Znanstveni Rad JAZU u Osijeku, 1984 (3), ss. 173-191.

Molnor, Monika. “Karlofça Antlaşması'ndan Sonra Osmanlı Habsburg Sınırı (1699- 1701)”, 
Osmanlı, C. I, Ankara: Yeni Türkiye Yayınları, 1999, ss. 472-479.

Novili Ömer Efendi. Tarih-i Bosna: Osmanlı-Habsburg Savaşlart 1736-1739, (haz.) Fatma Sel Turhan, İstanbul: Küre Yayınları, 2016.

Pešalj Jovan. Monitoring Migrations: The Habsburg-Ottoman Border in The Eighteenth Century, Doctoral Thesis, Universiteit Leiden, 2019.

Roider, Karl A. "The Perils of Eighteenth-Century Peacemaking: Austria and the Treaty of Belgrade, 1739”, Central European History, Sep., 1972, Vol. 5, No. 3 (Sep., 1972), ss. 195-207.

Roider, Karl A. Austria's Eastern Question, 1700-1790, New Jersey: Princeton University Press, 1982.

Roider, Karl A. The Reluctant Ally: Austria's Policy in the Austro-Turkish War,1737-39, Baton Rouge: Louisiana State University Press, 1972.

Solak, Mehmet. "Osmanl1-Habsburg Hudûd Tahdîdine Bir Örnek: Ziştovi Sonrası Bosna Hudûdunun Tafsilatı (27 Aralık 1795)”, Karadeniz Araştırmaları, 2020 (XVII/67), ss. 631-656.

Srkulj, Sij. "Uređenje Međa po Karlovačkom i Požarevačkom Miru”, Vjesnik Kraljevskog Hrvatskoslavonsko-Dalmatinskoga Zemaljskoga Arkiva, (ur.) Ivan Pl. Bojničić Kninski, Zagreb: Tisak Kralj. Zemaljske Tiskare, 1907, ss. 24-43.

Treaties Between Turkey and Foreign Powers. 1535-1855, London: Compiled by the Librarian and Keeper of the Papers, 1855.

Vaníček, František. Specialgeschichte der Militargrenze Aus Originalquellen und Quellenwerken Geschopft, I. \& II. Band, Wien: Hof- und Staatsdruckerei, 1875.

Vojna Enciklopedija, Knj. 1, Izdanje Redakcije Vojne Enciklopedije, Beograd, 1958.

Zinkeisen, Johann Wilhelm. Osmanlı Imparatorluğu Tarihi, (çev.) Nilüfer Epçeli, C.V, İstanbul: Yeditepe Yayınları,2011.

\section{Internet Kaynakları}

https://maps.hungaricana.hu/en/HTITerkeptar/22138/view/?bbox=4308\%2C9743\%2C7556\%2C-8386 Erişim Tarihi: 20.09.2020.

https://mapy.mzk.cz/mzk03/001/052/598/2619316507/ Erişim Tarihi: 20.09.2020

https://storage.googleapis.com/raremaps/img/xlarge/39890.jpg Erişim Tarihi: 20.09.2020.

https://curiosity.lib.harvard.edu/islamic-heritage-project/catalog/40-990119775810203941 Erişim Tarihi: 20.09.2020.

\section{Tablo İçerisinde Kullanılan Dipnotlar}

1 Srijem’deki Ostružnica köyünün kuzeydoğusunda bulunur.

2 Zdinska Ada günümüzde yoktur. Ada ismini Sava’nın sol tarafindaki Boljevac Köyü’nün yakınındaki ormandan (Zidina) almıştır.

3 Sava’nın sağ tarafında Kamičak köyünün kuzeyinde bulunur. 
4 Sava Nehri Kupinovo ve Klenak arasında sık sık yatağını değiştirir. Ada ismini Klenak köyünün doğusundaki Karakuš bölgesi ve ormanından almaktadır.

5 Krstac adası artık mevcut değildir. Klenak köyü yakınlarındaki Sava'nın sol kıyısında yer alan ada ismini Krstac ormanlarından ve bölgesinden almıştır.

6 Krstac adası yakınlarındaki eski bir nehir adası olan Vrbovačka, Sava'nın sol kıyısında yer alır.

7 Vrtić adası ismini Horvat-Pustara ve Radan-Bare arasında Srijemska Rača'nın doğusunda yer alan Vrtić adlı bir bataklığın isminden almıştır.

8 Bosut Nehri'nden yukarı, dört saat uzaklıkta Sava'nın sol tarafina yakın bir adadır. Bkz.: BOA. A.\{DVN.DVE.d... / 903, s. 2; Turan Gökçe, "1699-1700 Tarihli Bosna Vilâyeti Hududnâmesi”, Tarih İncelemeleri Dergisi, Say1: XVI, (2001), s. 83.

9 Gerçek bir nehir adası değildir. Ancak Sava Nehrinin sağında su seviyesinin yükselmesi sonucunda adaya dönüşen kara parçasıdır. Rača'dan Brod'a kadar sadece üç nehir adası (Donjoštitarska, Štitarska ve Brodska) vardır; Brod'dan Una ve Sava nehirlerinin birbirine karıştığı yere kadar herhangi bir nehir adası bulunmamaktadır.

10 Bosut Nehri'ne bir gün sekiz saat uzaklıkta olan ada, Sava Nehri'nin sol kıyısına yakındır. Bkz.: BOA. A.\{DVN.DVE.d... / 903, s. 2; T. Gökçe, “a.g.m.”, s. 83. 


\section{Ekler}

Ek 1. Osmanlı ile Habsburglar Arasında Una Suyu Sınırlarını Gösteren Karlofça' dan Ziştovi Muahedesine Kadar Yapılan Anlaşmalardaki İlgili Maddeleri Havi Defter. ${ }^{161}$

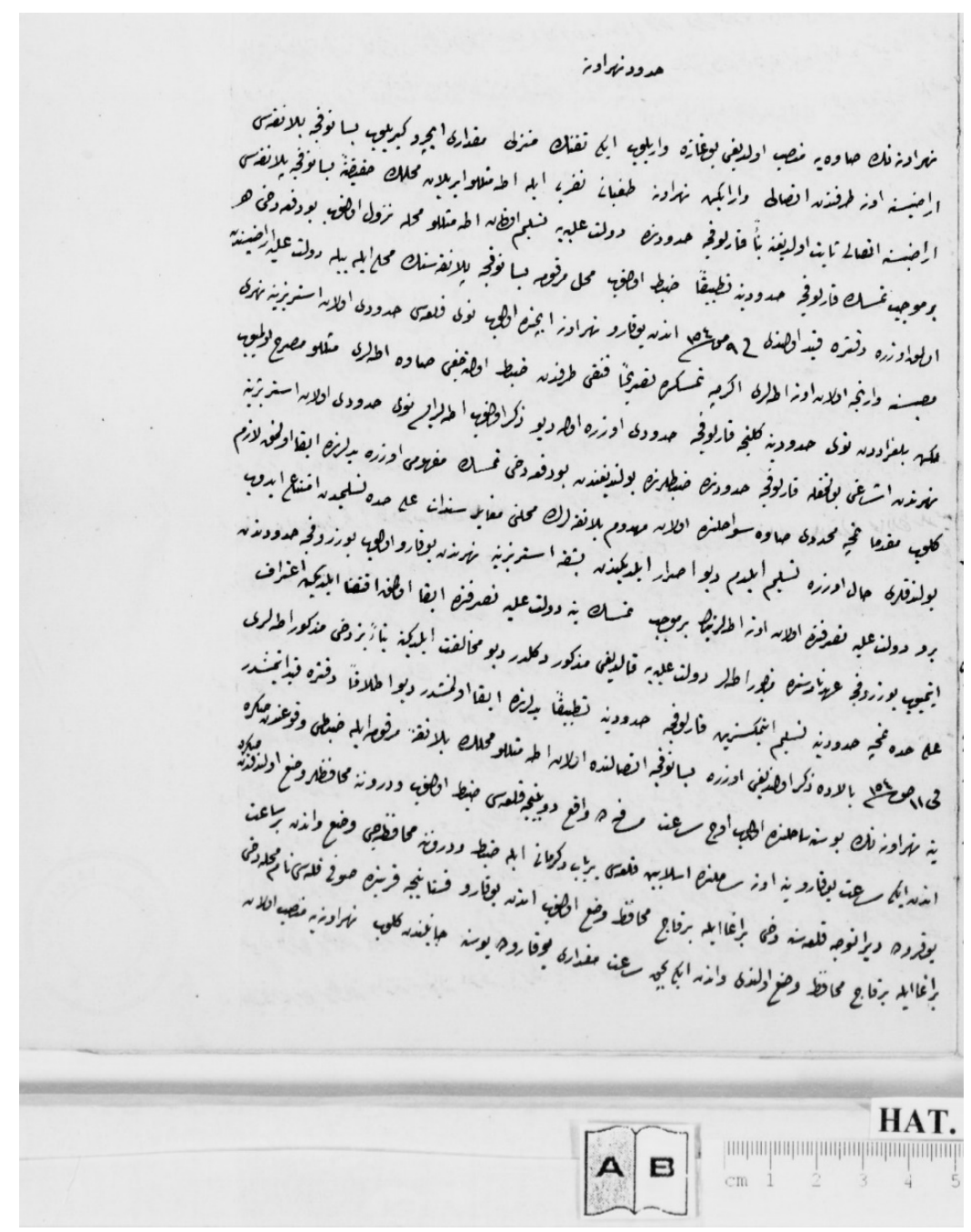




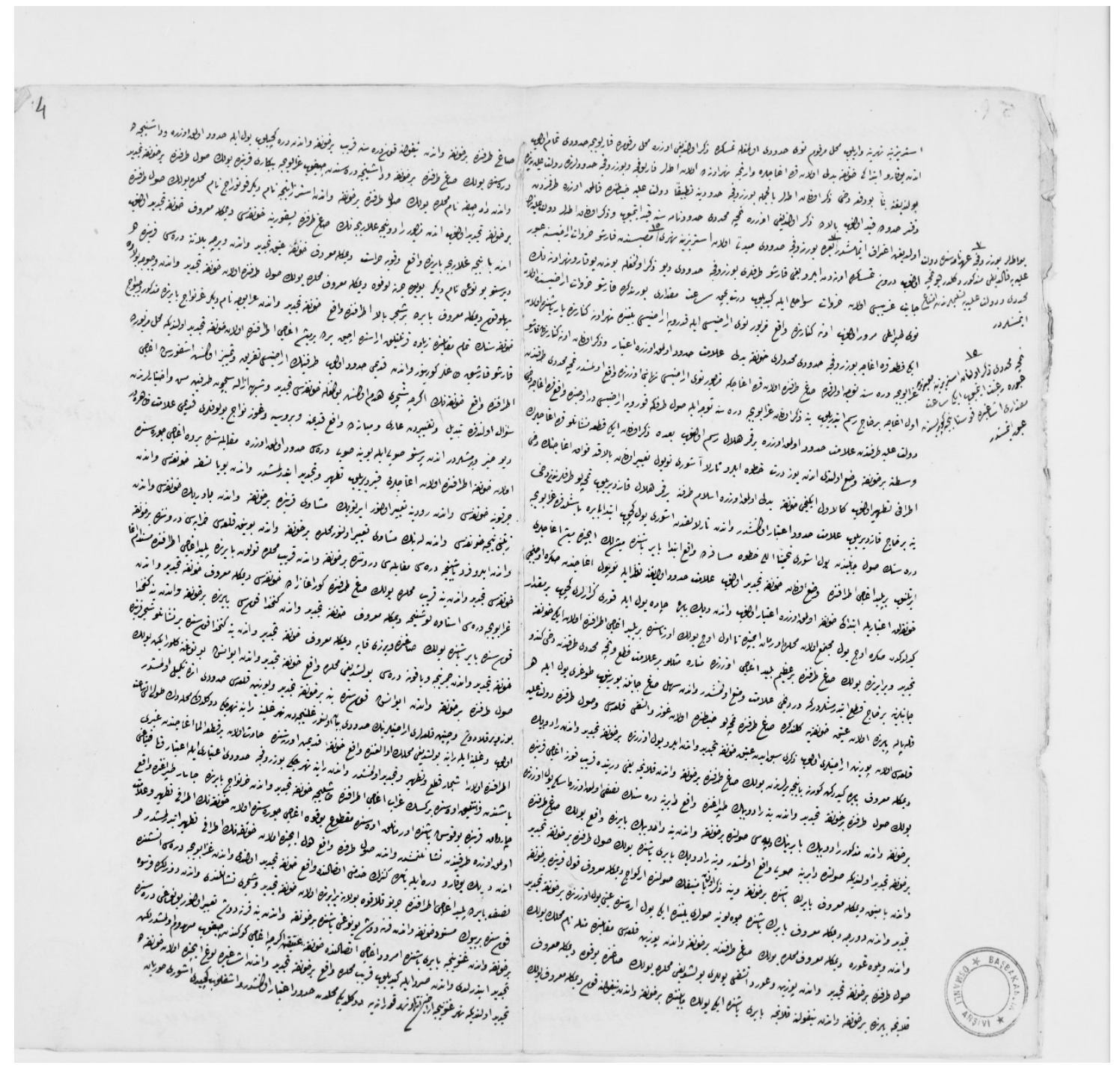


5

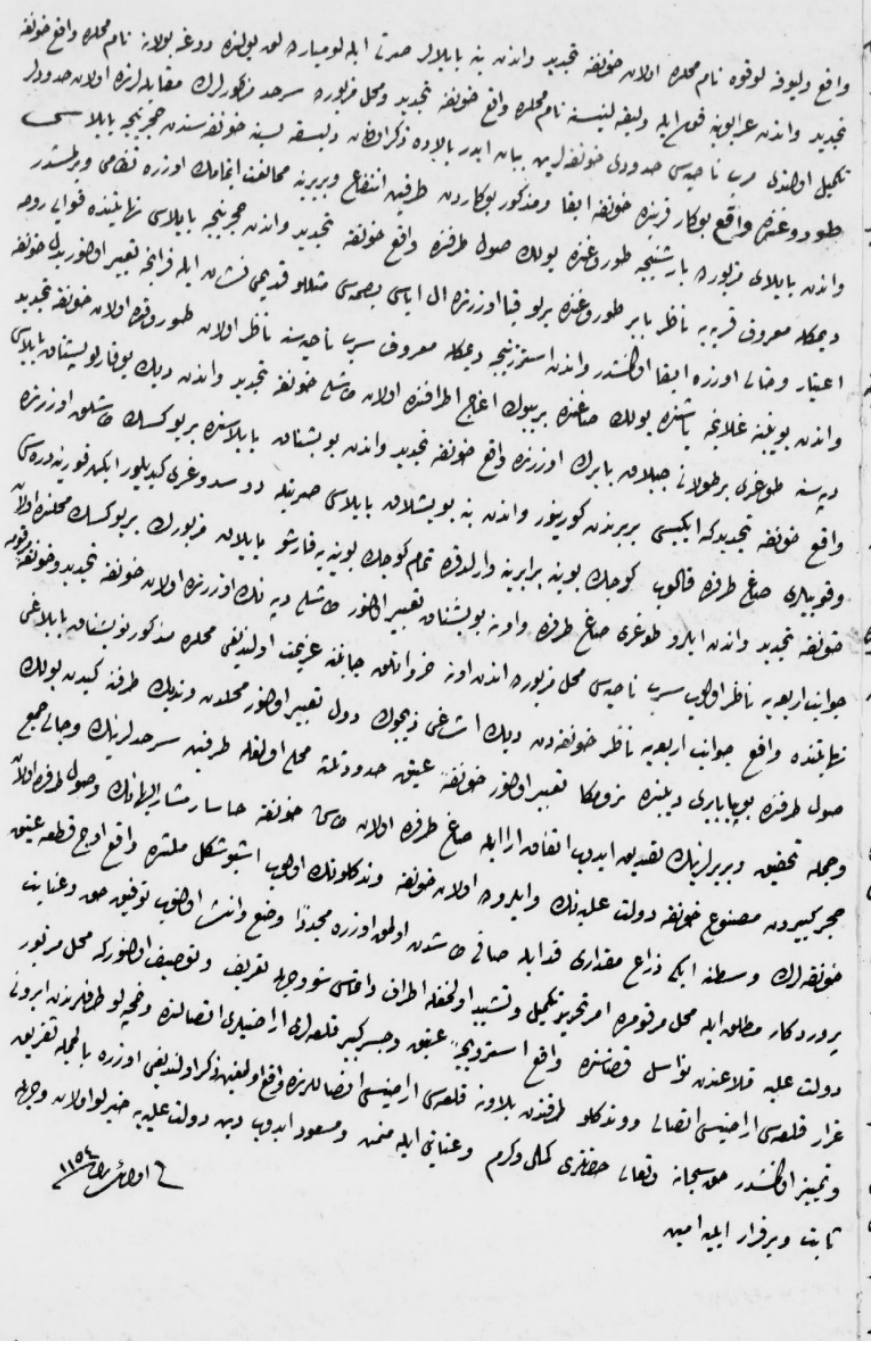


Ek 2. Hudûd-1 Selâse ${ }^{162}$

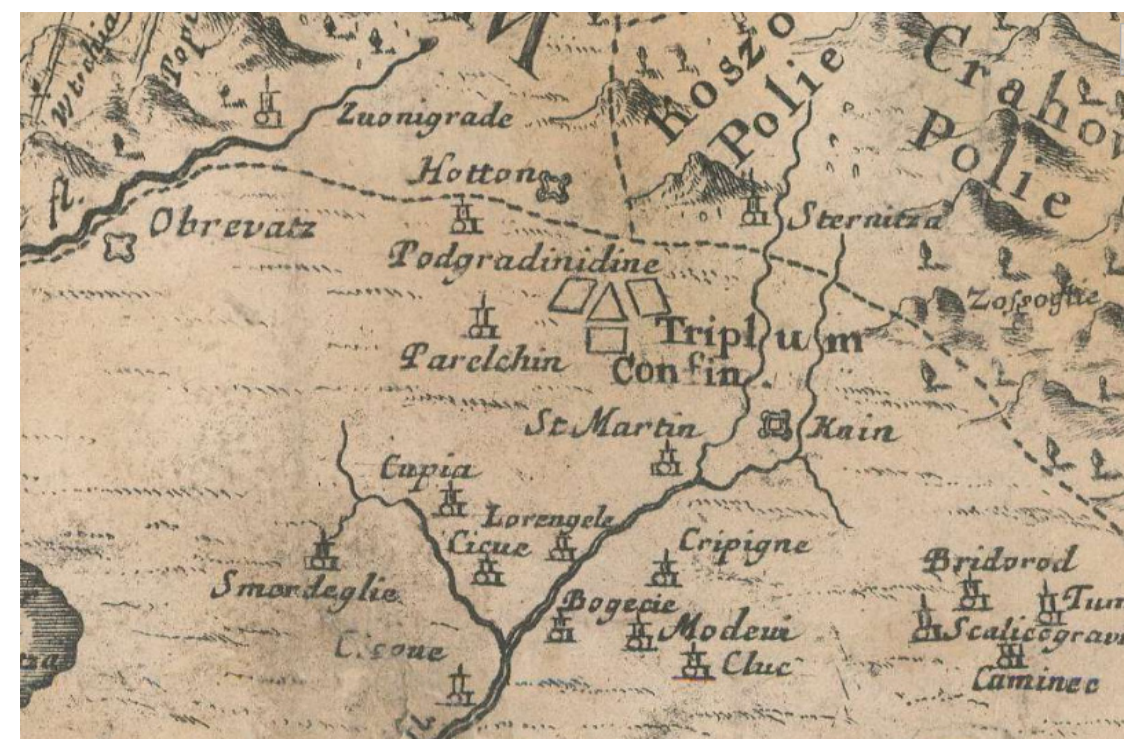

Ek 3. Frunia Bölgesi ${ }^{163}$

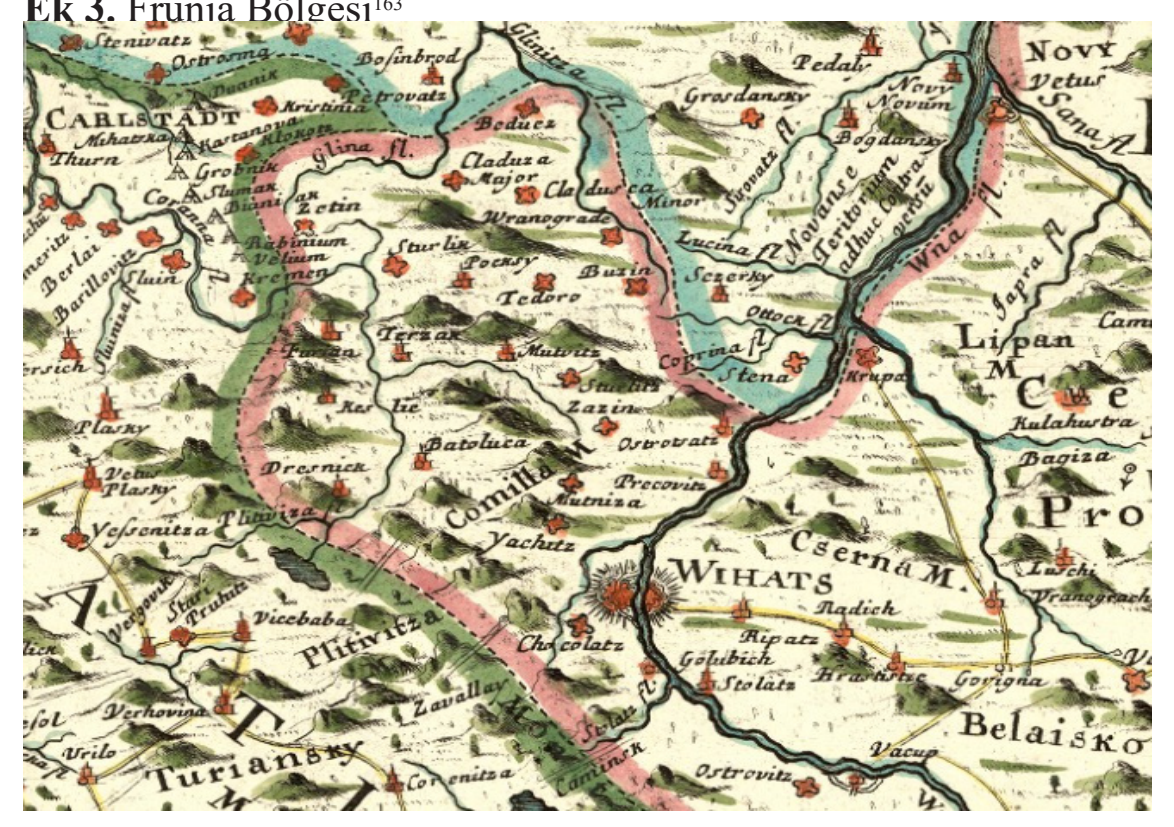

162 https://maps.hungaricana.hu/en/HTITerkeptar/22138/view/?bbox $=4308 \% 2 \mathrm{C}-$ 9743\%2C7556\%2C-8386 Erişim Tarihi: 20.09.2020.

163 https://mapy.mzk.cz/mzk03/001/052/598/2619316507/ Erişim Tarihi: 20.09.2020. 
Ek 4. Bosna Eyaletinin Sinırları (1740 / Renksiz) $)^{164}$

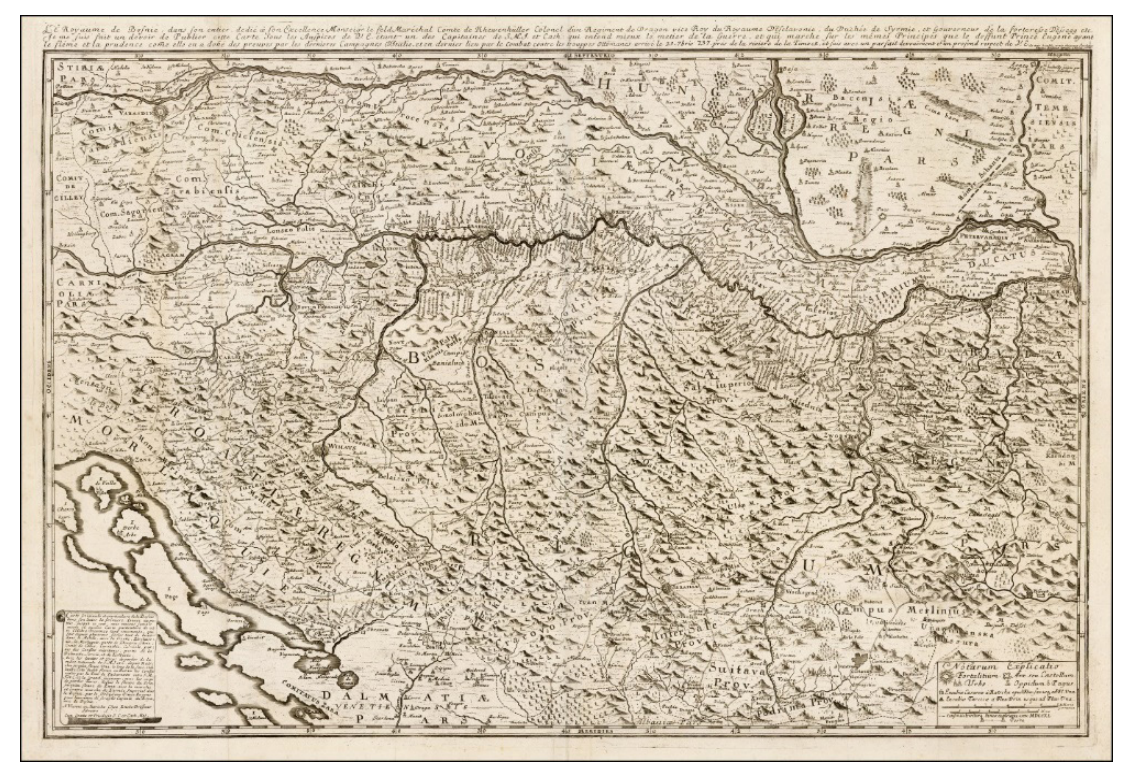

Ek 5. Bosna Eyaletinin Sinırları (1740 / Renkli) ${ }^{165}$

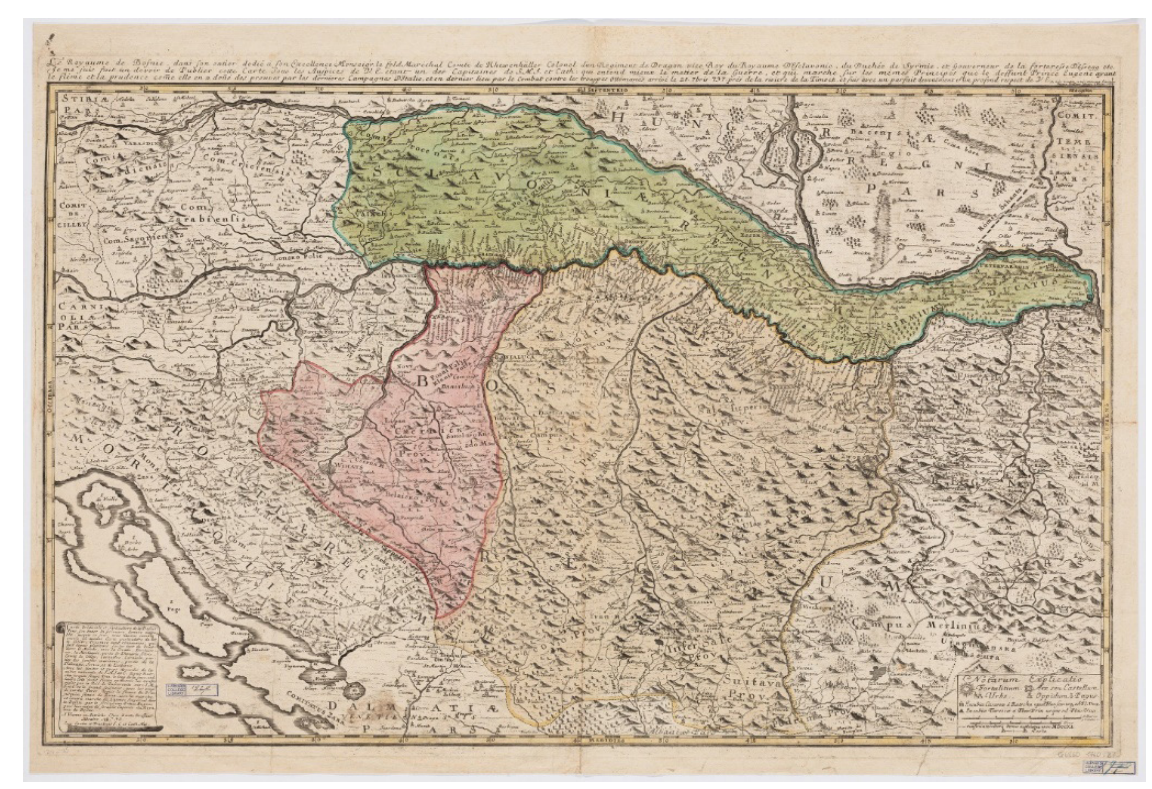

164 https://storage.googleapis.com/raremaps/img/xlarge/39890.jpg Erişim Tarihi: 20.09.2020. Feldmareşal Ludwig Andreas von Khevenhüller'e ithafen Etienne Briffuant tarafından hazırlanmış Bosna'nın ince detaylı haritasıdır. Harita batıda Varaždin ve Zagreb'den ve Senj'den doğuda Belgrad'a, Tuna ve Sava nehirlerinin seyrini takip ederek modern Hırvatistan, Bosna Hersek ve Sırbistan ülkelerini kapsiyor.

165 https://curiosity.lib.harvard.edu/islamic-heritage-project/catalog/40-990119775810203941 Erişim Tarihi: 20.09.2020. 